\title{
Análise comparativa dos dous últimos decretos de distribución de linguas no ensino galego
}

\author{
Analysis of last two decrees of language distribution in Galician education
}

\author{
Mario Gradín Martínez \\ Universidade de Vigo \\ mgradin@uvigo.es
}

\begin{abstract}
Resumo
Dende a entrada en vigor da Lei de normalización lingüística, a meirande parte dos esforzos a prol da recuperación e da dignificación social do galego foron dirixidos ao ensino non universitario, ao considerarse como un dos eidos de actuación principais. Porén, o tratamento que se lle deu á lingua galega nas aulas foi cualificado a miúdo como de mínimos ou de baixa intensidade, polo menos ata a chegada da coalición de goberno entre o Partido dos Socialistas de Galicia e o Bloque Nacionalista Galego: durante o seu período ao mando da Xunta, a devandita coalición aplicou o Decreto 124/2007, do 28 de xuño, polo que se regula o uso e a promoción do galego no sistema educativo. Este texto representa o maior avance rexistrado cara á normalización do idioma nas aulas, priorizándose o seu emprego para contrarrestar os usos sociais privilexiados (e dominantes) do castelán no resto da sociedade. Non obstante, coa vitoria do Partido Popular de Galicia nas eleccións do 2009, o Decreto 124 foi de rrogado e substituído polo Decreto 79/2010, do 20 de maio, para o plurilingüismo no ensino non universitario de Galicia, co que en esencia se suprimiu o tratamento favorable á lingua nas aulas e se fixo unha distribución igualitaria, baixo unha perspectiva estritamente cuantitativa, entre o galego e o castelán. Partindo disto, neste estudo elaboramos unha análise contrastiva de ambos os dous textos para amosar que modelos de educación bilingüe se aplicaron con cada decreto, intentando demostrar que a miúdo as políticas lingüísticas desenvoltas pola Xunta no ensino pretenderon manter a desigualdade entre as dúas linguas oficiais, máis que responder a un verdadeiro compromiso pola normalización do galego.
\end{abstract}

\section{Palabras-clave}

Normalización lingüística; lingua galega; ensino; bilingüismo; modelos de educación bilingüe; decretos
Enviado: 15/01/2019

Aceptado: 03/02/2020

\begin{abstract}
Since the application of the law of linguistic normalisation, most of the efforts to achieve the recuperation and the dignification of Galician language were addressed to education, because it was considered one of the main fields of involvement. However, the language treatment in the classrooms was frequently described as minimum or of low intensity until the arrival of the coalition government of the Partido dos Socialistas de Galicia and the Bloque Nacionalista Galego, which applied the Decreto 124/2007, do 28 de xuño, polo que se regula o uso e a promoción do galego no sistema educativo [2007/124 Decree, June 28, regulating the use and promotion of Galician in the education system]. This text represents the biggest advancement made for the normalisation of Galician language in the classroom, by prioritising its use in order to counteract the privileged (and dominant) social uses of Spanish in the other social areas. Nevertheless, when the Partido Popular de Galicia won the autonomic elections in 2009, the decree 124 was eliminated and replaced by Decreto 79/2010, do 20 de maio, para o plurilingüismo no ensino non universitario de Galicia [2010/79 Decree, May 20, for plurilingualism in non-university education in Galicia], so that a positive treatment of the Galician language was removed and this new government made an equitativave language distribution (just under a quantitative point of view) at school. Taking all this as a starting point, in this research we carry out a theoretical analysis of both texts to show which bilingual models were applied with each decree, aiming to show that the linguistic policies developed by the Xunta de Galicia frequently seem to be more related to ideological interests than to a real commitment to the Galician language.
\end{abstract}

\section{Keywords}

Linguistic normalisation; Galician language; education; bilingualism; bilingual education models; decrees 


\section{Sumario}

1. Introdución. 2. Principios metodolóxicos. 3. Precisión conceptual. 3.1. Definición asumida para o termo bilingüismo. 3.2. O alumnado galego, bilingüe?. 3.3. Noción tradicional do ensino bilingüe, monolingües por privilexio e bilingües por necesidade. 3.4. Hipótese da interdependencia lingüística e posibles modelos de educación bilingüe: inmersión, mantemento e submersión. 3.5. Cataluña e os programas de inmersión e mantemento do catalán. 4. Análise dos decretos 124/2007 e 79/2010. 4.1. Decreto 124/2007: o ensino como un axente compensatorio do galego. 4.1.1. Educación Infantil: introdución á lectoescritura en galego nas contornas urbanas e lingua predominante da contorna. 4.1.2. Primaria, ESO e Bacharelato: o galego como lingua vehicular e lingua de interacción nun mínimo do $50 \%$ das clases. 4.1.3. Un modelo de inmersión parcial para castelanfalantes e un modelo de mantemento para galegofalantes. 4.2. Decreto 79/2010: unha diferenciación entre o igualitario e o equitativo. 4.2.1. Educación Infantil: consulta aos pais e lingua predominante na contorna. 4.2.2. Primaria, ESO e Bacharelato: reparto igualitario de linguas por materias e liberdade idiomática do alumnado. 4.2.3. Un modelo de submersión para castelanfalantes. 5. Conclusións e reflexión final.

\section{Contents}

1. Introduction. 2. Methodological principles. 3. Conceptual precision. 3.1. Definition assumed for the term bilingualism. 3.2. Galician students, bilingual? 3.3. Traditional notion of bilingual education, monolingual by privilege and bilingual by necessity. 3.4. Hypothesis of linguistic interdependence and possible models of bilingual education: immersion, maintenance and submersion. 3. 5. Catalonian and the immersion and maintenance programmes of Catalan. 4. Analysis of decrees 2007/124 and 2010/79. 4.1. Decree 2007/124: teaching as a compensatory agent of Galician. 4.1.1. Infant Education: introduction to literacy in Galician in the urban environments and the predominant language of the environment. 4.1.2. Primary, Secondary and A-Levels: Galician as a vehicular language and language of interaction in a minimum of $50 \%$ of the classes. 4.1.3. A model of partial immersion for Spanish speakers and a model of maintenance for Galician speakers. 4.2. Decree 2010/79: A differentiation between what is egalitarian and what is equitable. 4.2.1. Infant Education: consult to parents and predominant language of the environment. 4.2.2. Primary, Secondary and A-Levels: equal distribution of languages by subjects and language freedom of students. 4.2.3. A submersion model for Spanish speakers. 5. Conclusions and final thoughts.

\section{Introdución}

U NHA vez finalizado o período de represión franquista, a aprobación da Constitución Española do 1978 supuxo a consideración da diversidade lingüística de España por primeira vez en décadas. No seu terceiro artigo, establécese o castelán como a lingua oficial de todo o Estado, recaendo en todos os españois "o deber de cońecelo e o dereito de usalo", ademais de recońecerse a oficialidade das linguas autóctonas empregadas nalgunhas comunidades autónomas, de acordo cos seus estatutos, e a necesidade do seu respecto e protección (Constitución Española 1978: 29332).

Por outra banda, no Estatuto de Autonomía de Galicia do 1981 establécese o galego como o idioma propio desta comunidade, así como unha das súas linguas oficiais, xunto ao castelán. Porén, no Estatuto non se implanta o deber de cońecemento do galego por parte da cidadanía, tal e como si ocorría co castelán, segundo o estipulado na Constitución; en todo caso, afírmase que tanto o galego coma o castelán "son oficiais en Galicia e todos teñen o dereito de coñecelos e usalos" (Ley Orgánica 1/1981: 8997). 
Para intentar suplir esta distinción de estatus entre ambas as dúas linguas, inicialmente no primeiro artigo da Lei de normalización lingüística do 1983, considerada como o texto legal de referencia do que se derivarían as normas en materia lingüística máis concretas (Silva, 2010: 41-42), estipulábase que todos os galegos e galegas tiñan o deber e o dereito de usalos. Non obstante, este punto foi derrogado polo Tribunal Constitucional despois dun recurso de inconstitucionalidade interposto polo goberno central, argüíndo que este deber non se recollía na Constitución, por unha banda, e que a cooficialidade do galego en Galicia non xustificaba esta decisión, por outra. Neste senso, coincidimos con Monteagudo e Bouzada cando afirman que "esta importante corrección tería significativa influencia no desenvolvemento posterior da lei" (2002: 50-51).

Sexa como for, e á marxe desta diferenza legal de base entre os dous idiomas, despois de máis de corenta anos Galicia dispón dun amparo lexislativo para desenvolver medidas de normalización lingüística que persigan deter (e reverter) o proceso de substitución lingüística que sufriu a lingua galega dende finais da Idade Media, e que se viu especialmente acentuado dende principios do século xx.

Unha das características fundamentais das políticas lingüísticas da Xunta dos últimos trinta e cinco anos é a seguinte: a meirande parte dos esforzos a prol do galego foron dirixidos ao contexto educativo, ao considerarse como un dos ámbitos máis relevantes para garantir unha mellora dos usos, as actitudes e as competencias lingüísticas na lingua por parte das novas xeracións (Seminario de Sociolingüística 2016: 201). Esta decisión, cómpre engadir, parece sustentarse no aumento do grao de influencia da escola para garantir a aprendizaxe do galego: de acordo cos datos achegados polo Instituto Galego de Estatística (IGE de agora en adiante), en tan só dez anos manifestouse un aumento de 13 puntos entre a porcentaxe do $2003(30,1 \%)$ e a do 2013 (43,17\%) (Seminario de Sociolingüistica 2016: 50). Esta situación resulta comprensible se consideramos que, nas últimas décadas, o aumento do número de familias monolingües en castelán e o descenso da transmisión xeracional do galego foi moi notable, especialmente nas contornas urbanas, polo que o ensino se constitúe nestes casos como o principal contexto de aprendizaxe desta lingua (Seminario de Sociolingüística 2016: 50; 190).

A grandes trazos, as políticas lingüísticas desenvoltas pola Xunta de Galicia durante máis de tres décadas no ensino poderían denominarse como non conflitivas, baseadas en tímidos avances cara á lingua autóctona, pero que contribuían a manter unha situación desigual de seu. Esta afirmación é apoiada por investigadores como Lorenzo e Subiela, que cualificaron a lexislación lingüística que foi aplicada no ensino ata a chegada do Decreto 124/2007 como "de baixa intensidade" e "de mínimos", respectivamente (2005: 46; 2002: 131-171). Os contidos que se manexan a continuación poden servir para demostrar que o emprego destes termos está xustificado e lexitimado.

Dende a entrada en vigor do Real Decreto 1981/1979, co que se establece a materia de Lingua galega e literatura como obrigatoria nas antigas etapas de Educa- 
ción Preescolar, Educación Xeral Básica e Formación Profesional de Primeiro Grao (Ministerio de Educación, 21 de agosto do 1979: 19550), os decretos de distribución de linguas posteriores (xa amparados na Lei de normalización lingüística) que se sucederon ata o decreto actual, o 79/2010, caracterizáronse por introducir un aumento progresivo da presenza do galego nos centros; de feito, este último é o único elaborado ata o momento que supón unha regresión respecto á introdución da lingua no ensino, como veremos máis adiante. Con todo, ata a entrada en vigor do decreto da coalición de goberno entre o Partido dos Socialistas de Galicia e o Bloque Nacionalista Galego, o 124/2007, nas aulas seguía a estar presente un tratamento lingüístico que, na práctica, favorecía ao castelán. Neste senso, cómpre desenvolver esta idea máis polo miúdo.

Durante os anos en que o Decreto 247/1995, precedente ao 124/2007, estivo en vigor, o galego debía ser a lingua impartida nun mínimo de dúas áreas de cońecemento (o equivalente a aproximadamente un terzo do horario semanal), deixando á elección dos centros o idioma no que debían impartirse o resto de materiais. Non obstante, non había para o alumnado unha obriga explícita de empregar o galego nas materias destinadas ao seu uso: en todo caso, o profesorado debía procurar que o seu uso se convertese nunha realidade, pero sen indicarse no decreto pautas concretas para acadar este obxectivo, ou desenvolvendo unha inspección de rigor que comprobase o seu cumprimento (Consellería de Educación e Ordenación Universitaria, 14 de setembro do 1995: 2-3). Se a isto lle sumamos a precaria situación do idioma propio na Educación Infantil, onde os nenos de familia galegofalante carecían "do dereito a seren escolarizados na súa lingua, ante a pasividade xeral" (Monteagudo \& Bouzada 2002: 61), e lembramos ademais que todos os decretos aplicados ata a chegada do bipartito supoñían un escaso avance respecto do establecido no texto anterior, poderemos comprender por que as políticas lingüísticas (máis que de normalización lingüística) que desenvolveu a Xunta no ensino durante case vintecinco anos foron denominadas coa etiqueta, antes mencionada, de "baixa intensidade" (Lorenzo 2005: 46).

Non obstante, esta situación mudou debido á aprobación no Parlamento de Galicia, por unanimidade de todas as forzas políticas do momento (Partido Popular de Galicia, Partido dos Socialistas de Galicia e Bloque Nacionalista Galego²), do Plan xeral de normalización da lingua galega no 2004. En esencia, neste texto recollíanse unha serie de principios orientadores para intentar acadar como obxectivo último a normalización lingüística plena, isto é, a igualdade efectiva entre o castelán e o galego en todos os ámbitos da sociedade. Entre as medidas destinadas ao ensino, destacan as seguintes: na Educación Primaria, na Educación Secundaria Obrigatoria e Bacharelato, a implantación dun mínimo do $50 \%$ de horas totais de cada curso impartidas en

1. Para cońecer en maior profundidade tódalas ordes e decretos de distribución de linguas no ensino aplicados pola Xunta dende a aplicación do Estatuto ata o Decreto 247/1995, véxase Monteagudo e Bouzada (2002: 54-61).

2. PPdG, PsdG e BNG de agora en adiante. 
galego e a obrigatoriedade de que o alumnado empregue esta lingua como a vehicular nas materias destinadas ao seu uso e, en Educación Infantil, a realización de actividades de iniciación á lectoescritura neste idioma en tódolos centros, incluídos os situados en contornas castelanfalantes, de maneira que o galego sexa o idioma vehicular nun mínimo do $50 \%$ do horario total de todos os centros do primeiro ensino (Xunta de Galicia 2006: 102-104) .

Estes compromisos recollidos no plan foron asumidos pola coalición entre o BNG e o PSdG: durante a sétima lexislatura de Galicia, este goberno bipartito elaborou o texto legal no que se establecería o maior grao de presenza do galego no ensino que se rexistrou ata o de agora: falamos do Decreto 124/2007, do 28 de xuño, polo que se regula o uso e a promoción do galego no sistema educativo (Consellería de Educación e Ordenación Universitaria, 29 de xuño do 2007: 11247-11251). Baseado no establecido no Plan xeral para o ámbito educativo, no decreto recóllese este mínimo do $50 \%$ do horario impartido en galego para todas as etapas educativas, coa obriga adicional, por parte do alumnado, de empregar esta lingua nas materias respectivas na Educación Primaria, na Educación Secundaria Obrigatoria e no Bacharelato. En esencia, con este texto fíxose unha discriminación positiva do galego na escola, co obxectivo de contrarrestar as diferenzas de privilexios entre esta lingua e o castelán no resto da sociedade. Como afirma Iglesias (2017: 55), "este decreto resérvalle ao ensino un papel compensatorio: se o galego se encontra minorizado fóra da escola, cómpre priorizalo nela".

Non obstante, todos os avances acadados polo texto do bipartito víronse truncados co retorno ao goberno da Xunta do PPdG, liderado por Alberto Núñez Feijóo. No 2009, os conservadores derrogaron o devandito decreto e substituírono polo Decreto 79/2010, do 20 de maio, para o plurilingüismo non universitario de Galicia (Consellería de Educación e Ordenación Universitaria, 25 de maio do 2010: 9242-9247), que por primeira vez en case trinta anos de políticas lingüísticas supuxo un retroceso no proceso de inclusión da lingua galega nas aulas. Cun reparto lingüístico distribuído a partes iguais, o total de materias impartidas en galego nos niveis de Educación Primaria e Educación Secundaria Obrigatoria non poden superar o 50\%, porcentaxe que se reduce a un 33\% no caso dos centros que incorporan unha lingua estranxeira (xeralmente inglés) como o terceiro idioma vehicular: pásase, pois, dunha lexislación lingüística de mínimos a unha de máximos. Por outra banda, o factor da obrigatoriedade idiomática elimínase (isto é, o alumnado xa non ten por que empregar o galego nas materias destinadas ao seu uso), e na Educación Infantil xa non ten cabida a lectoescritura nesta lingua nos xa mencionados centros que teñen unha maioría de alumnado co castelán como lingua inicial, polo que se retorna á situación anterior, na que simplemente se usa na clase a lingua predominante na contorna. Con este procedemento, vólvese perpetuar a xa tradicional distinción entre a Galicia urbana e a rural.

Considerando as notables diferenzas entre o Decreto 124/2007 e o 79/2010, que serán analizadas máis polo miúdo nas seccións 4.1. e 4.2., podemos inferir que 
o pouso ideolóxico que subxace a ambos os dous textos é ben distinto. No que a este estudo respecta, intentaremos extraer estas ideoloxías mediante unha análise dos modelos de educación bilingüe (inmersión, mantemento e submersión) aplicados en cada caso, o que, de maneira paralela, nos permitirá obter unha comprensión xeral sobre o tratamento de linguas nas aulas que realizou cada goberno (a coalición entre o BNG e o PSdG, por un lado, e o PPdG, por outro) cos dous últimos decretos.

\section{Principios metodolóxicos}

Como sinalamos na Introdución, neste traballo realizamos unha análise dos dous últimos decretos de distribución de linguas no ensino que elaborou a Xunta de Galicia, isto é, o 124/2007 e o 79/2010. Para isto, combinamos os resultados da análise destes textos con algunhas das referencias básicas sobre o papel das linguas no ensino e os modelos de educación bilingüe de autores como Baker (1997), Cummins (1983), ou Lambert (1981). Con este procedemento, pretendemos comprobar cales destes modelos son aplicados con cada decreto, apoiándonos nas achegas dos investigadores que os empregaron para describir a lexislación lingüística de Galicia enfocada ao ensino, isto é, Iglesias (2017: 53-56) e Fernández, Lorenzo e Ramallo (2008: 63-65). Isto permitiranos, en última instancia, inferir que ideoloxías lingüísticas se obteñen de cada decreto, e por extensión de cada goberno.

Ao complementar a análise dos decretos coas achegas sobre os modelos de educación bilingüe, cómpre empregarmos unha terminoloxía de rigor para ter un coñecemento máis sistematizado e exacto do tratamento do galego e do castelán que se fai en cada decreto. Por este motivo, para este estudo optamos por recorrer aos conceptos de inmersión, mantemento e submersión, que se ben constitúen de seu unha clasificación simplificada das múltiples etiquetas utilizadas, permiten asociar as políticas lingüísticas que se desenvolveron nos dous textos con modelos concretos e delimitados.

Finalmente, tamén cómpre mencionar que neste traballo unicamente nos centramos nas partes dos decretos en que se especifica o reparto de linguas por materias e as obrigas idiomáticas de profesorado e alumnado, ao considerarmos que son os factores que máis inflúen nos posteriores usos, actitudes e competencias lingüísticas da mocidade. Porén, non debemos esquecer que neste texto se especifica o grao de presenza do galego no ensino dende outras perspectivas: o seu uso por parte da administración educativa, o funcionamento dos equipos de normalización, os casos de exención da propia materia de lingua, etc. 


\section{Precisión conceptual}

Tendo en conta que na análise dos decretos intentaremos establecer cales son os modelos de educación bilingüe que con eles se aplican, debemos adicar unha parte do estudo a aclarar, na medida do posible, toda a confusión denotativa que con frecuencia rodea a conceptos como bilingüismo e educación bilingüe. Polo tanto, non debe sorprendernos que precisamente estas palabras, empregadas a miúdo no discurso leigo, presenten unha confusión denotativa que mesmo custa delimitar na propia linguaxe especializada.

\subsection{Definición asumida para o termo bilingüismo}

Debido á xa mencionada falta de consenso sobre a definición deste concepto, así como á variedade de contextos en que pode ser empregado o termo, debemos partir dunha distinción inicial que permita saber se nos referimos a un bilingüismo centrado no falante, na medida na que este dispón dunha certa competencia de dúas ou máis linguas, ou na sociedade á que pertence, entendida como un conxunto de cidadáns dos que a maioría son bilingües. É o que investigadores como Siguán e Mackey denominan "bilingüismo individual" e "bilingüismo social", respectivamente (1986: 17).

Considerando os contidos que se manexan neste artigo, a nós interésanos a perspectiva individual do concepto, ao intentar esclarecer que tipos de bilingüismo se obteñen coa aplicación de cada decreto. De acordo cos mesmos autores, que fan unha definición do termo baseada no grao de competencia, estes entenden ao falante bilingüe como a persoa "que, ademais da súa primeira lingua, ten unha dominio parecido noutra e é capaz de usar unha e outra en calquera circunstancia con parecida eficacia” (Siguán \& Mackey 1986: 17). Como cabe esperar, isto non se corresponde co dominio real que os falantes bilingües adoitan ter das súas linguas ${ }^{3}$ : en calquera caso, case sempre está presente un desequilibro acentuado entre o idioma ou idiomas iniciais e os que son adquiridos posteriormente. Porén, Siguán e Mackey utilizan esta definición como un modelo perfecto de referencia, a partir do que se poden valorar os diferentes graos de bilingüismo de cada falante (1986: 17-18).

Non obstante, e a pesar do carácter ideal desta definición, o certo é que na bibliografía especializada utilizouse a miúdo esta concepción do bilingüismo non como modelo, senón como unha representación errónea da realidade lingüística. Seguindo

3. De feito, en calquera territorio con linguas en contacto adoita haber un reparto desigual non só de competencias, senón tamén de usos e actitudes, cun idioma privilexiado e outro desprestixiado. Por este motivo, esta idea dun bilingüismo equilibrado ten aínda menos posibilidades de corresponderse co uso real e social das linguas. 
a Baker (1997: 34-35), o termo non sempre se empregou con rigor, e utilizouse para abranguer graos de competencia nunha segunda lingua que non se corresponderían co verdadeiro bilingüismo. Neste senso, fala de dous casos extremos de bilingüismo: o máximo ou equilibrado, equivalente á noción "perfecta” de Siguán e Mackey, e o incipiente, empregado para calquera falante cunha competencia mínima nun segundo idioma. Por isto, o propio Baker (1997: 34-35) rexeita considerar a este perfil de falantes como bilingües, pois por unha banda é moi pouco habitual atopar un falante "real" que presente un dominio equiparable en varias linguas, tal e como viñemos sinalando nas lińas anteriores, mentres que por outra un cońecemento mínimo dun idioma non sobrepasa a simple capacidade memorística dos trazos básicos do código, e que está moi afastada do complexo sistema cognitivo que subxace ao dominio de calquera fala.

Deste xeito, neste artigo seguimos unha definición do bilingüismo baseada nas competencias, pois o grao de dominio das linguas é un dos principais temas de análise deste traballo, en función dos modelos de ensino bilingüe que se desenvolveron cos dous decretos en que aquí nos centramos. De feito, a concepción do bilingüismo dende a perspectiva do dominio tamén se recolle no artigo 14.3 da Lei de normalización lingüística, ao establecerse a necesidade de que "ó remate dos ciclos en que o ensino do galego é obrigatorio, os alumnos coñezan este, nos seus niveis oral e escrito, en igualdade co castelán” (Xunta de Galicia, 14 de xullo do 1983: 4).

\subsection{O alumnado galego, bilingüe?}

No que a Galicia respecta, cuestionarios como os elaborados polo IGE parecen indicar que a práctica totalidade da cidadanía galega podería considerarse minimamente bilingüe, pois os resultados amosan competencias considerablemente altas tanto na produción como na comprensión oral e escrita. De acordo cos datos fornecidos polo IGE na súa última enquisa sobre o cońecemento e o uso do galego, realizada no 2013, un $96 \%$ dos galegos e galegas afirman entender a lingua na dimensión oral, e un $85 \%$ considera que a pode ler sen dificultades. Se nos centramos agora na vertente expresiva, un $86 \%$ cre posuír unha capacidade efectiva para falar en galego (a porcentaxe máis alta de todas as comunidades cunha lingua distinta ao castelán, cómpre engadir) e un 60\% para escribir neste idioma (Seminario de Sociolingüística 2016: 37-40).

Todo isto, cómpre engadir, sen que destaquen diferenzas moi considerables entre os que teñen un maior dominio dunha lingua ou doutra: da porcentaxe total de persoas que manifestaron ter mellores competencias en castelán que en galego ${ }^{4}$, un $68 \%$

4. Neste senso, cómpre matizar que no IGE en ningún momento se elabora unha clasificación de competencias en función da lingua habitual dos enquisados; en todo caso, séguese o criterio de "maior dominio do castelán" ou "maior dominio do galego". 
cre posuír unha competencia efectiva na expresión oral da lingua galega, un $77 \%$ na comprensión lectora e un $43 \%$ na expresión escrita (Seminario de Sociolingüística 2016: 48); o dominio da comprensión oral, considerando que a inmensa maioría de Galicia entende o idioma do país, non se tivo en conta. Deste xeito, a excepción da expresión escrita, que a pesar da súa progresiva mellora (debido á implantación do galego como materia obrigatoria) sempre amosa porcentaxes de adquisición efectiva inferiores ás competencias orais, unha parte moi considerable dos galegos que afirman ter un maior dominio do castelán manifesta posuír unha competencia aceptable na lingua galega.

No que atinxe ás competencias lingüísticas en castelán, o IGE non recompilou datos ao respecto, ao partir da premisa de que "case a totalidade, senón a totalidade, dos galegofalantes son capaces de entender e utilizar o castelán, ainda que non ocorre á inversa" (Seminario de Sociolingüística 2016: 38). De feito, se marcamos o último fragmento do texto anterior en cursiva, débese a que precisamente esta desigualdade de competencias entre galegofalantes e castelanfalantes (os primeiros dominan con fluidez ambas as dúas linguas, pero os segundos non) constitúe o principal argumentario daqueles que defenden unha priorización da lingua galega nas aulas, tal e como veremos máis adiante. Porén, esta afirmación resulta contraditoria aos resultados amosados no parágrafo anterior, que fan pensar que a práctica totalidade dos galegos ten unha competencia axeitada nos dous idiomas, isto é, unha competencia bilingüe, sen diferenzas significativas entre os galegofalantes e os castelanfalantes. A que se debe isto?

As enquisas elaboradas polo IGE, que mencionamos máis arriba, están baseadas en estudos de autopercepción de competencias; noutras palabras, son os propios falantes os que manifestan a súa impresión sobre o seu dominio da lingua galega nas vertentes oral e escrita. Por este motivo, pode ocorrer que as respostas achegadas polos participantes non reflictan a realidade sociolingüística de Galicia, de maneira que as competencias en galego por parte dos castelanfalantes, especialmente os asentados nas contornas urbanas, non sexan tan positivas como suxiren este tipo de estudos.

No 2010, o Instituto de Ciencias da Educación da USC publicou os resultados dun proxecto de investigación, dirixido por Bieito Silva, co que se pretendía avaliar as competencias en galego e castelán do alumnado de $4^{\circ}$ da ESO. A grandes trazos, a media da competencia xeral en galego foi, sobre un total de 5, dun 3,66 para a expresión oral e dun 2,77 para a expresión escrita (o dominio da comprensión non se considerou no estudo) (2010: 109; 62). En ambos os dous casos, os resultados son inferiores á competencia amosada en castelán, que se corresponde cun 3,77 para a expresión oral e cun 3,04 para a expresión escrita (Silva 2010: 121; 82). Dito doutro xeito, e como afirma Pérez (2011:294), "sen ser a competencia lingüística plenamente satisfactoria en ningún dos dous idiomas, o alumnado remata o ensino obrigatorio cunha competencia superior en castelán ca en galego”. 
Por outra banda, outros dous aspectos destacables dos resultados deste traballo tamén residen nas puntuacións obtidas nas subcompetencias avaliadas, así como na importancia das variables que inflúen nestas mesmas puntuacións. $\mathrm{Na}$ dimensión oral, o alumnado obtivo os mellores resultados na adecuación sociolingüística con 3,81 puntos, e na coherencia e na cohesión con 3,7, mentres que as subompetencias con puntuacións máis baixas foron as de cońecemento do léxico, con 3,54 puntos, e a do saber gramatical, con 3,63 (Silva 2010: 110). Contrastando estes resultados cos obtidos en castelán, atopámonos con que neste caso ocorre exactamente o contrario: as subcompetencias con mellores puntuacións son as dúas que acabamos de mencionar $(3,89$ puntos na gramática e 3,8 no léxico), mentres que a subcompetencia da adecuación se reduce a 3,71 puntos (Silva 2010: 82).

Á hora de comparar as puntuacións obtidas na dimensión escrita de ambas as dúas linguas, as diferenzas entre o galego e o castelán acentúanse aínda máis: neste caso, o alumnado obtivo unha media de 2,81 puntos para a subcompetencia da adecuación sociolingüística, por unha banda, e de 2,77 e 2,74 para a gramática e o léxico, por outra. Isto diverxe dos resultados en castelán, lingua na que os discentes presentaron unha media de 2,91 puntos na adecuación (sensiblemente inferior á puntuación en galego) e de 3,13 e 2,12 na gramática e o léxico (Silva 2010: 62; 82).

Considerando os preocupantes datos sobre a perda da transmisión xeracional da lingua galega nos últimos anos (o que provocou que, no 2013, só un $25 \%$ da mocidade de entre 5 e 14 anos tivese o galego como lingua única ou habitual, de acordo cos datos do IGE), resulta comprensible que a escola aumentase o seu grao de importancia como axente determinante para garantir xa non só un aumento dos usos lingüísticos en galego, senón a adquisición dunha competencia mínima nesta lingua por parte dos discentes castelanfalantes, tal e como vimos na Introdución. Porén, os resultados deste estudo, o de maior amplitude desenvolto ata o de agora en Galicia, lévannos a interpretar que o goberno autonómico está a incumprir o artigo da Lei de normalización xa mencionado ao fin da epígrafe 3.1, isto é, o 14.3, no que se establece a necesidade de que o alumnado dispoña dunha competencia equiparable nas dúas linguas oficiais ao remate de cada ciclo educativo obrigatorio (Xunta de Galicia, 14 de xullo do 1983: 4).

Non obstante, parece que este desequilibro de competencias non se produce, polo menos de maneira tan acentuada, no alumnado que ten o galego como lingua habitual. No 2014, Loredo e Silva publicaron un traballo no que, partindo da análise dos resultados do estudo ao que nos vińemos referindo nos parágrafos anteriores, establecen cales son as variables que inflúen en maior ou menor medida na adquisición das competencias lingüísticas por parte do alumnado de 4. ${ }^{\circ}$ da ESO. Segundo os propios autores, "os resultados indican que ter unha boa competencia gramatical e léxica en galego inflúe de maneira positiva nas mesmas competencias en castelán, circunstancia que non se produce á inversa" (a cursiva é nosa) (Loredo \& Silva 2014: 205). 
Para intentar atopar unha explicación a esta diferenza de competencias entre castelanfalantes e galegofalantes, pode resultar esclarecedor o seguinte texto de Costas. Neste, destácase que o predominio do castelán na práctica totalidade dos contextos da sociedade galega garante que toda Galicia teña unha competencia axeitada neste idioma, mentres que en moitas ocasións certos sectores, como a mocidade castelanófona das contornas urbanas, apenas ten contacto co galego, o que dificulta a súa aprendizaxe:

Verbo da competencia bilingüe dos galegos, quen acada hoxe en día con máis facilidade o bilingüismo galego-castelán? Só os galegofalantes, xa que o castelán (que é obrigatorio, segundo a Constitución) o pode aprender calquera en ámbitos e medios moi diversos: escola, televisión, xornais, cómics, cinema, radio, música, igrexa, administración, empresa, sanidade, grandes superficies comerciais etc.

En troques, os castelanfalantes urbanos novos, agás parcialmente nos centros de ensino, en que outros lugares teñen oportunidade de se facer competentes en galego? En moi poucos, así que dificilmente poderán ser bilingües; o máis previsible é que acaden un bo dominio dunha lingua (castelán) e un dominio insuficiente ou simplemente dominio pasivo da outra (galego).

En suma: nas condicións actuais, as persoas que realmente se fan bilingües son as galegofalantes, algo que non ocorre coas castelanfalantes. De feito, na xeración dos menores de 30 anos, na Galicia urbana, hai xa unha porcentaxe elevada de monolingües en castelán que teñen graves dificultades para se expresar nun galego oral minimamente aceptable (Costas 2009: 27-28).

Tendo en conta esta diferenza de usos lingüísticos, baseados nunha maior cantidade de espazos reservados para o emprego do castelán que do galego, os defensores do Decreto 124/2007 concibiron o ensino como un axente compensador da desigualdade lingüística presente no resto da sociedade galega para conseguir o equilibro. Esta igualdade intentaríase acadar mediante unha priorización do galego na escola, ao considerar esta medida como a única posible para obter unha mocidade plenamente bilingüe, de acordo co estipulado no artigo 14.3. da Lei de normalización, antes mencionado.

\subsection{Noción tradicional do ensino bilingüe, monolingües por privilexio e bilingües por necesidade}

Tradicionalmente, supoñíase que unha exposición temperá a unha lingua distinta da inicial podía representar un desenvolvemento cognitivo e lingüístico negativos para o falante. Noutras palabras, considerábase que o procesamento de calquera tipo de información nun segundo idioma supoñía non só o deterioro de todas as linguas 
involucradas no proceso, senón tamén o retraso na aprendizaxe do coñecemento. Neste senso, existen traballos sobre educación bilingüe en que se expońen como, nunha mesma aula, o alumnado bilingüe era precisamente o que presentaba os resultados máis deficitarios na adquisición dos coñecementos e na competencia lingüística. Como afirma Cummins (1983: 38), hipóteses como "o efecto balanceo", coa que o dominio dunha segunda lingua se traduce nunha perda equivalente de competencia na primeira, ou a que defende que a escolarización nun idioma distinto do inicial equivale a un retraso académico do neno, foron as máis empregadas para soster que a educación bilingüe implicaba "confusión mental" e "hándicap" no individuo.

Atopámonos, pois, ante unha concepción absolutamente negativa da educación bilingüe que se ve sostida por ideas como as que acabamos de mencionar. Non obstante, cómpre sinalarmos un aspecto clave: ao longo de toda esta lińa de investigación tradicional sobre educación bilingüe, ningún dos especialistas deu en sinalar que estes resultados deficitarios se podían deber a outros factores de índole social, e non necesariamente aos estritamente lingüísticos. En calquera territorio con linguas en contacto, adoita estar presente un reparto de contextos de uso prexudicial para unha delas: nestes casos, pode acontecer que a lingua dominante e de maior prestixio social estea vencellada aos usos lingüísticos de prestixio, ademais de contar coas actitudes máis favorables por parte da cidadanía, independentemente do idioma que esta utilice; por outra banda, tamén é probable que a lingua dominada, xeralmente a autóctona, sexa empregada nos ámbitos informais de menor consideración e conte coas actitudes máis negativas.

A situación que acabamos de describir correspóndese co contexto sociolingüístico de Galicia anterior ás políticas de normalización iniciadas nos oitenta: nesta época, os galegofalantes víanse obrigados a adquirir competencias en castelán, ao mesmo tempo os castelanfalantes podían permanecer na súa posición de monolingües, sen que en ningún momento se lles esixise aprender o galego (Vila 2012: 5). Para comprender esta diferenza de xerarquías lingüísticas entre o galego e o castelán e, ademais, dispoñer de etiquetas específicas para cada grupo, nós propoñemos os conceptos de monolingües por privilexio para os castelanfalantes e os de bilingües por necesidade 5 para os galegofalantes, pois poden resultar útiles para describir o contexto sociolingüístico galego que é anterior ao inicio das políticas de normalización lingüística dos oitenta. Noutras palabras, ao non existir naquel momento medidas concretas que buscasen potenciar os usos e as competencias en galego no ensino, a mocidade galegofalante non dispońía de contextos en que adquirir unha competencia escrita baseada na lectura e na escritura da súa lingua, aínda que si acadaba un dominio (tanto oral como escrito do castelán), mentres que os castelanfalantes tiña un acceso moito menor á

5. Ao concibirmos aos monolingües como privilexiados e aos bilingües como prexudicados, unicamente falamos dende a perspectiva dos usos: os galegofalantes víanse forzados a renunciar á súa lingua propia en numerosas ocasións, vulnerándose os seus dereitos lingüísticos, mentres que os castelanfalantes podían permanecer no seu monolingüismo sen dificultades. 
aprendizaxe da lingua galega en calquera das catro modalidades (falar, entender, ler e escribir).

Porén, a partir dos decretos de distribución de linguas do ensino que se derivaron da Lei de normalización esta situación cambiou: se ben é certo que, tal e como sinalamos ao inicio deste traballo, nestes textos se seguía priorizando o uso do castelán nas aulas (ata a chegada do Decreto 124/2007), resulta evidente que a introdución do ensino do (e en) galego nunha parte do currículo permitiu superar a situación de "bilingüismo asimétrico" (isto é, na que os galegofalantes eran bilingües e os castelanfalantes permanecían illados no seu monolingüismo) das décadas anteriores. Como proba disto, convén acudir aos resultados amosados no primeiro volume do Mapa Sociolingüístico de Galicia do 1992, xa que neste ano xa se comezan a apreciar os resultados da escolarización parcial en galego: concretamente, un $80,3 \%$ dos enquisados de entre 16 e 25 anos afirma ter un bo dominio do galego falado, un $72,9 \%$ da lectura e un $64,1 \%$ da escritura, mentres que a práctica totalidade de informantes afirma entender o galego sen dificultades (Seminario de Sociolingüística 1994: 82). Tendo en conta que, neste mesmo ano, xa un 53,4 dos enquisados situados neste tramo de idade afirma ser total ou maioritariamente castelanfalante (Seminario de Sociolingüística 1995: 50), podemos concluír que nos últimos anos do século xx os castelanfalantes xa tiñan acceso a unha aprendizaxe parcial en galego, á marxe do tipo de competencias nesta lingua que posuísen ao rematar o ensino obrigatorio e do seu grao de presenza nas aulas, que foi variando con cada novo decreto. En función destes dous últimos factores, podemos falar de diferentes modelos de ensino bilingüe, que neste traballo denominamos como modelos de inmersión, mantemento e submersión de linguas.

\subsection{Hipótese da interdependencia lingüística e posibles modelos de educación bilingüe: inmersión, mantemento e submersión}

No 1965, na provincia canadense de Quebec, Wallace Lambert e Wilder Penfield realizaron varios traballos de investigación sobre educación bilingüe con grupos experimentais de inmersión en francés para alumnado de familias anglófonas, co obxectivo de acadar a dignificación deste idioma nun país no que había unha desigualdade moi acusada entre o inglés, o idioma de prestixio, e o francés, vencellado aos grupos de poboación co status socioeconómico máis baixo. Así pois, despois do consentimento das familias anglófonas participantes no programa, xa que desexaban o bilingüismo para os seus fillos, ao longo de toda a súa escolarización obrigatoria este perfil de alumnado, que tińa o inglés como lingua inicial, recibiu unha educación monolingüe en francés nos primeiros anos de educación, a medida que se ía introducindo o inglés de maneira progresiva nos cursos posteriores. 
A diferenza dos resultados obtidos nas investigacións precedentes, os resultados destes grupos amosaron que o desenvolvemento académico, lingüístico e cognitivo dos nenos sometidos á inmersión podía supoñer a adquisición, a longo prazo, dunha maior "flexibilidade cognitiva" por parte dos discentes (Lambert 1981: 172). No seguinte texto, o propio Lambert compendia os principais beneficios que se obtiveron da aplicación dos programas, que parecen indicar que o alumnado anglófono do programa de inmersión en francés conseguiu unha competencia lingüística neste idioma moito máis próxima á dos nenos francófonos cá dos nenos anglófonos que estudaban o francés como unha lingua estranxeira:

Después de quince años de evaluación hemos constatado que este nuevo programa de enseñanza en la segunda lengua no ha producido ningún tipo de déficit en la lengua nativa ni en los contenidos escolares. No aparece ningún retraso que pueda ser atribuido a la participación en el programa. Yendo aún más lejos, los resultados proporcionan argumentos para considerar que se produce cierto enriquecimiento cognitivo atribuible a la experiencia. Los nińos del grupo experimental eran capaces de leer, escribir, hablar, entender y utilizar el inglés tanto como sus compañeros instruidos en inglés por el procedimiento convencional.

En lo que respecta al funcionamiento cognitivo, los alumnos experimentales de sexto grado puntúan, como clase, al mismo nivel que las pruebas en medidas estándar de inteligencia y significativamente más altos en medidas de flexibilidad cognitiva (Lambert 1981: 171-172).

Visto o anterior, semella que os discentes do programa de inmersión non só acadaron unha competencia lingüística máis completa, senón que ademais o seu desenvolvemento intelectual é comparable ao dos nenos educados co modelo convencional, pero coa vantaxe de obter unha maior flexibilidade cognitiva que se corresponde cun sistema lingüístico máis desenvolto. Indo aínda máis lonxe con esta idea, o propio Lambert (1981: 173) destaca que os resultados do programa poderían ser mellores se o alumnado se desenvolvese nunha contorna totalmente francofonizada, isto é, realizando unha inmersión total. Porén, a pesar da desvantaxe que puidese supoñer o predominio do inglés no resto de ámbitos da sociedade, a priorización do francés na escola pareceu ser suficiente como para acadar un bilingüismo equiparable en ambas as dúas linguas. Atopámonos, unha vez máis e como acontecía en Galicia no debate sobre o Decreto 124/2007, coa defensa dunha discriminación positiva ou compensación desta lingua a través do ensino para que toda a cidadanía dun territorio acade o bilingüismo, contrarrestando deste xeito o reparto desigual de usos e actitudes no resto de contextos comunicativos.

Baseándose nos resultados de varias investigacións precedentes sobre os métodos de ensino bilingüe, Cummins elaborou a hipótese da interdependencia lingüistica, coa que defende que a exposición a unha segunda lingua pode ser moi positiva se o fa- 
lante ten suficientemente asentado o seu cońecemento da lingua inicial. Dáse, deste xeito, unha relación de reciprocidade entre as linguas empregadas por un mesmo falante, relación que adquire especial relevancia á hora de acadar unha segunda lingua, xa que o falante usará de maneira combinada os seus idiomas cando se dea calquera tipo de aprendizaxe. Algunhas das vantaxes da devandita hipótese son compendiadas por Baker no fragmento que representamos a continuación:

A primeira é que os bilingües poden ter un rango de experiencias máis amplo e variado cós monolingües debido a que operan con dúas linguas e, probablemente, con dúas ou máis culturas.

A segunda explicación refírese ao mecanismo da alternancia de código. Porque os bilingües alternan entre as súas dúas linguas, poden ser máis flexibles no seu modo de pensar. A terceira explicación denomínase proceso de obxectivación. Un bilingüe pode conscientemente e subconscientemente comparar e contrastar as súas linguas. Inspeccionar as dúas linguas, resolver a interferencia entre linguas, pode conferirlle ao bilingüe destrezas metalingüísticas (1997: 182-183).

Seguindo de novo a Baker (1997: 229-220), son catro os factores que determinan os modelos de educación bilingüe: a) o perfil dos falantes aos que vaian dirixidos (monolingües ou bilingües); b) o tratamento de linguas que se faga nas aulas; c) os obxectivos lingüísticos do sistema; e d) o tipo de bilingüismo que se queira obter coa aplicación do programa. Partindo destes criterios, atoparémonos con que nun territorio con contacto de linguas poderanse empregar diferentes modelos educativos, distribuídos ao longo dun continuo con diversas posibilidades, e cos seguintes extremos: a) un modelo pensado para que os falantes da lingua minorizada abandonen este idioma e empreguen o dominante, derivando na obtención de falantes nun inicio monolingües no uso, e a longo prazo tamén en competencias ao abandonar a lingua propia; e b) a súa contraparte, coa que se realiza unha escolarización integramente na lingua autóctona, permitindo aos seus falantes que a manteńan e asegurando que os falantes da lingua hexemónica se convertan en bilingües. Atopámonos, polo tanto, ante unha postura utilitarista e prexudicial para a diversidade lingüística, por unha banda, e con outra comprometida pola variedade idiomática e cos dereitos lingüísticos de todas as persoas, tanto individuais como colectivos, pola outra.

Aínda que o propio Baker fala de ata dez modelos de educación bilingüe, para este traballo optamos por establecérmonos unha clasificación máis simplificada, na que cada categoría poida ser susceptible de diferentes graos de aplicación e permita atopar unha equivalencia directa entre os modelos teóricos e os decretos de distribución de linguas no ensino que analizaremos nos Resultados. En consecuencia, para a seguinte clasificación aproveitamos as achegas feitas ao respecto por Iglesias (2017: 53-56) e Fernández, Lorenzo e Ramallo (2008: 63-65), que como mencionamos no capítulo 2 constitúen as únicas referencias do ámbito da bibliografía especializada 
galega nas que se aplica a terminoloxía dos modelos de ensino bilingüe aos Decretos 124/2007 e 79/2010:

- Modelo de inmersión: con este tipo de educación bilingüe faise unha priorización da lingua minorizada nas aulas. Tamén recibe a denominación de modelo de enriquecemento (Fernández, Lorenzo \& Ramallo 2008: 65), pois está pensado para que os falantes da lingua hexemónica (monolingües) engadan un novo idioma ao seu sistema cognitivo e lingüístico, desenvolvendo un bilingüismo aditivo.

- Modelo de mantemento: este modelo está orientado a que os falantes bilingües (isto é, os falantes da lingua autóctona) conserven o idioma dominado, evitando na medida do posible que a acción asimiladora da lingua dominante derive nunha perda da que lles é propia. Na práctica, o que se pretende é que os falantes bilingües acaden un resultado positivo en usos (evitando a perda da lingua) e actitudes cara á variedade autóctona.

- Modelo de submersión: dirixido aos falantes da lingua minorizada, constitúe un xeito de que o alumnado bilingüe adquira os trazos lingüísticos e culturais do grupo dominante, coa conseguinte perda do idioma propio; por este motivo é tamén denominado modelo de asimilación (Fernández, Lorenzo \& Ramallo 2008: 66), acadándose ademais un bilingüismo substractivo.

Nun territorio con linguas en contacto, resulta obvio que, partindo da clasificación anterior, só poderemos garantir a normalización da lingua autóctona mediante a aplicación dos dous primeiros modelos; o ensino, deste xeito, desempeñaría o papel compensatorio ou equilibrador ao que nos vińemos referindo durante as páxinas anteriores. $\mathrm{O}$ modelo asimilatorio, pola contra, será desenvolto por unhas autoridades que desexan manter esta desigualdade lingüística, para o que se adoitan empregar estratexias como a "naturalización" ou a "lexitimación" do seu discurso (Sánchez 2018: 16-17) que permiten que esta discriminación sexa aceptada polos propios falantes da lingua autóctona, ou mesmo percibida como o lóxico.

\subsection{Cataluña e os programas de inmersión e mantemento do catalán}

Dentro do Estado español, Cataluña representa o exemplo máis claro da aplicación dos modelos de inmersión e mantemento, en función de cal sexa o perfil lingüístico do alumnado: mediante a introdución do uso do catalán como a lingua prioritaria do ensino, nas últimas décadas a Generalitat veu desenvolvendo un modelo de inmersión para os discentes castelanfalantes, de maneira que poidan ter acceso á 
aprendizaxe dunha lingua que se ve subordinada ao predominio do castelán no resto da sociedade, e un modelo de mantemento para os catalanfalantes, co obxectivo de acadar a competencia escrita neste idioma e evitar que o ensino funcione como un axente castelanizador. Deste xeito, e tendo en conta os resultados positivos dos grupos experimentais de Canadá que se acadaran dúas décadas antes, tal e como acabamos de compendiar brevemente, a partir do curso 1992-1993 tódolos centros públicos de Cataluña desenvolvían os modelos de inmersión e mantemento (Plataforma per la Llengua 2018: 11). Isto, como afirma Serra (2006: 160), "foi posible gracias a un consenso político básico entre a cidadanía sobre a importancia do cońecemento de ambas as dúas linguas, e sobre o feito de que a lingua socialmente débil, a catalá, debía ter a consideración de lingua forte na educación escolar”.

Co obxectivo de refutar os argumentos que se esgrimiron en contra dos modelos de inmersión e mantemento de linguas aplicados en Cataluña, no 2011 a Universitat Oberta publicou os Resultats del model lingüistic escolar de Catalunya: l'evidència empirica (Strubell et al. 2011), un estudo no que un grupo de expertos analizou os resultados dos informes PISA (tanto desta Comunidade Autónoma coma doutras do resto do Estado) nos anos anteriores, co obxectivo de avaliar as habilidades cognitivas, os coñecementos académicos e as competencias lingüísticas en castelán e en catalán do alumnado de Cataluña. A grandes trazos, os especialistas que participaron na elaboración da investigación, a máis ampla realizada ata o de agora nesta comunidade, pretendían dar resposta a cuestións como a que se o alumnado castelanfalante ten dificultades para aprender nunha lingua que non é a súa, se se está a acadar unha competencia en castelán inferior ao catalán, ao só estar presente a primeira lingua na propia materia de Lingua castelá e literatura, e se existen problemas para que este perfil de estudantes acade unha competencia axeitada en catalán se non se fai un uso prioritario deste no ensino, entre outras interrogantes (Strubell et al. 2011: 7). No que a este artigo respecta, só nos ocuparemos brevemente das tres que foron mencionadas.

Comezando pola primeira das cuestións, no informe afírmase que as dúbidas sobre a correcta adquisición dos coñecementos académicos do alumnado castelanfalante de Cataluña que está escolarizado nos programas de inmersión non están xustificadas (Vila 2011a: 11-13). Mediante unha comparación dos resultados obtidos en diversas competencias (comprensión lectora, coñecementos matemáticos, expresión lectora, etc), entre os estudantes castelanfalantes de Cataluña e os castelanfalantes doutras Comunidades Autónomas, chégase á conclusión de que a variable da lingua empregada no ensino non parece ser significativa para a adquisición dos cońecementos escolares: na maioría dos casos, os discentes cataláns amosaban resultados similares, ou incluso superiores, ao do alumnado doutros territorios en que o alumnado si estaba escolarizado na súa lingua propia (o castelán). Nas excepcións nas que se se presentan resultados significativamente inferiores aos doutras comunidades, extraeuse que influían outras variables alleas ao idioma vehicular das aulas, "implicadas na práctica educativa e na organización escolar" (Vila 2011a: 13). 
No que atinxe á interrogante sobre se o alumnado do programa de inmersión adquire unha competencia axeitada en castelán, Cortès-Colomé (2011:23-27) analiza varios estudos realizados ao longo de varios cursos nos niveis de Educación Primaria e Educación Secundaria Obrigatoria. No que atinxe á primeira etapa, a autora sinala que, no curso 1993-1994, case 400 estudantes cataláns e castelanfalantes participaron nun estudo para avaliar o seu dominio de ambos os dous idiomas; unha metade dos enquisados era alumnado escolarizado en catalán, e a outra metade en castelán. Mentres que ambos grupos amosaban competencias moi semellantes en ambas as dúas linguas (con diferenzas de menos de dous puntos), o cońecemento do catalán por parte dos estudantes escolarizados en castelán era moi inferior ao do alumnado do programa de inmersión (amosándose diferenzas de ata vinte puntos) (Cortès-Colomé 2011: 24). O mesmo ocorre na etapa de Educación Secundaria, onde se compararon, entre outros aspectos, as competencias en castelán de estudantes da ESO cos doutras Comunidades Autónomas: nesta ocasión, as diferenzas entre Cataluña e o resto do Estado español eran practicamente mínimas (Cortès-Colomé 2011: 24). Todo isto leva á investigadora a afirmar que, en definitiva, "os nenos e os adolescentes cataláns non saben menos castelán polo feito de estar escolarizados en catalán” (Costès-Colomé 2011: 27).

Finalmente, para tratar a cuestión do perigo da adquisición de competencias en catalán se non se prioriza este idioma na escola, Vila (2011b: 29-31) baséase en tres estudos diferentes para demostrar que o único xeito de que o alumnado de Cataluña adquira unha competencia axeitada nesta lingua é mediante os programas de inmersión para castelanfalantes e os de mantemento para catalanfalantes. No primeiro destes traballos, a comparativa entre un modelo de ensino en catalán e outro en castelán demostra que o dominio do catalán é moito maior no primeiro modelo ca no segundo; no segundo estudo, contrástanse dous grupos de $2^{\circ}$ da ESO, dos anos 2002 e 2004, escolarizados nos modelos de inmersión e mantemento do catalán, demostrándose que, a pesar do maior dominio desta lingua na dimensión oral, a competencia escrita está máis desenvolta en castelán; por último, a terceira investigación está dirixida á análise das variables que inflúen en maior medida, entre as que destaca a contorna sociolingüística (isto é, un ámbito catalanfalante facilitará a adquisición de competencias axeitadas en catalán). Se a estes resultados lles sumamos os argumentos esgrimidos nos dous parágrafos anteriores, cos que os cońecementos académicos e as competencias en castelán vense garantidas, interpretaremos que a priorización do catalán no ensino, traducida nos programas de inmersión e mantemento, resulta fundamental en Cataluña para obter unha mocidade bilingüe.

Recuperando os contidos manexados na epígrafe 3.2., hai dous aspectos que poderían xustificar a necesidade da aplicación en Galicia dos programas de inmersión e mantemento da lingua galega: a) o alumnado remata o ensino obrigatorio cunha competencia en galego inferior ao castelán; e b) os discentes galegofalantes posúen unha competencia máis equilibrada en ambos os dous idiomas (e polo tanto máis bilingüe), o que parece estar xustificado pola predominio do castelán nos contextos 
alleos á escola. Por outra banda, os resultados positivos obtidos noutros territorios onde se aplicaron estes modelos de ensino parecen reforzar a idea dunha priorización do galego nas aulas.

Neste senso, non existe en Galicia un estudo que analice en profundidade os efectos do Decreto 124/2007, o que introduciu en maior grao o uso do galego no ensino ata o de agora, nas competencias lingüísticas do alumnado. En todo caso, aínda que contamos co estudo do Instituto de Ciencias da Educación da USC, sobre o que nos centramos na mencionada epígrafe 3.2., o escaso período no que estivo en vigor o decreto do bipartito (tres cursos académicos), non foi suficiente para que se notasen os efectos da súa aplicación. Con todo, estudos de caso realizados en centros de Educación Infantil en que se realizaron proxectos experimentais de inmersión en galego, así como varios traballos críticos cos principios recollidos no Decreto 79/2010, axudan a interpretar que o ensino galego requería dos dous modelos de ensino bilingüe que viñemos mencionando nestas páxinas, co obxectivo último de que o alumnado acade unhas competencias plenamente bilingües. No seguinte capítulo, tras analizar os textos de ambos os dous decretos e algúns dos estudos publicados ao respecto, intentaremos inferir que modelos de ensino bilingüe aplicou cada goberno e que tipo de ideoloxías lingüísticas se lles poden adscribir.

\section{Análise dos decretos 124/2007 e 79/2010}

\subsection{Decreto 124/2007: o ensino como un axente compensatorio do galego}

En setembro do 2004, as tres forzas políticas que tiñan representación parlamentaria en Galicia nese momento (PPdG, PSdG e BNG) aprobaron na cámara autonómica o Plan xeral de normalización da lingua galega, no que se integran un conxunto de propósitos cos que se pretende acadar a dignificación e a recuperación social do idioma en todos os ámbitos de Galicia. No segundo sector do Plan, adicado ao ensino, á familia e á mocidade, destácase a necesidade de garantir unha competencia axeitada na lingua por parte do profesorado e do alumnado, promover o seu uso maioritario nas aulas nas interaccións co docente e co resto de compañeiros e aumentar a súa presenza na Educación Infantil, ao considerarse un dos niveis educativos máis castelanizados (Xunta de Galicia 2006: 94).

Partindo dos datos recollidos no Mapa Sociolingüistico de Galicia 1992', no Plan destácanse varios problemas que afectan de maneira directa á normalización da lingua, como son a perda da transmisión xeracional do galego, a competencia desigual entre os dous idiomas oficiais, máis desenvolta en castelán, e o mantemento dunhas

6. Non esquezamos que estes tres volumes anteceden aos publicados polo Seminario no 2007, no 2008 e no 2011. 
actitudes aínda reticentes cara ao galego e máis favorables cara á lingua estatal (Xunta de Galicia 2006: 79-80).

Co obxectivo de cumprir os preceptos recollidos no Plan xeral, no 2007 a coalición de goberno entre nacionalistas e socialistas derrogou o Decreto 247/1995, xa descrito brevemente na Introdución deste artigo, e substituíuno polo Decreto 124/2007, do 28 de xuño, polo que se regula o uso e a promoción do galego no sistema educativo (Consellería de Educación e Ordenación Universitaria, 29 de xuño do 2007: 1124711251). Así, xa no seu preámbulo se destaca a validez do devandito Plan, a necesidade de normalizar a lingua nos ámbitos de uso máis relevantes e a falta de adecuación do decreto anterior aos principios asumidos dende o 2004 (a cursiva é nosa):

O Plan xeral de normalización da lingua galega, aprobado por unanimidade no Parlamento de Galicia en setembro do 2004, establece como un dos seus obxectivos xerais conseguir para a lingua galega máis funcións sociais e máis espazos de uso, e dálle prioridade á súa presenza en sectores estratéxicos.

O Decreto 247/1995, do 14 de setembro, polo que se desenvolve a Lei 3/1983 de normalización lingüística para a súa aplicación ao ensino en lingua galega nas ensinanzas de réxime xeral impartidas nos diferentes niveis non universitarios, recoñece que a adquisición dunha competencia comunicativa en galego por parte do alumnado só se pode conseguir a través da utilización vehicular desta lingua nunha parte significativa do curriculo (Xunta de Galicia, 29 de xuño do 2007: 11247).

Tal e como se destaca no fragmento anterior, o bipartito apoia os principios recollidos no Plan xeral, especialmente nos referentes ao ensino. Isto é así ata o punto de que o Decreto 124/2007 contén puntos en que se reproducen literalmente fragmentos do texto do Plan, especialmente aqueles dedicados ao tratamento da lingua nos principais niveis de educación, e que se poden resumir en tres aspectos clave que xa mencionamos: a introdución do galego mediante a lectoescritura en Educación Infantil e, tanto neste nivel como na Educación Primaria e na Educación Secundaria Obrigatoria, a impartición dun mínimo do $50 \%$ das clases de cada curso en galego, coa obriga de que profesores e discentes utilicen en todo momento esta lingua nas materias destinadas ao seu uso (Xunta de Galicia, 29 de xuño do 2007: 1124811249). Non obstante, debemos tratar cada un destes puntos algo máis polo miúdo.

\subsubsection{Educación Infantil: introdución á lectoescritura en galego nas contornas urbanas e lingua predominante da contorna}

Ata a entrada en vigor do Decreto 124/2007, tódolos decretos de distribución de linguas que se foran sucedendo dende a aplicación da Lei de normalización recollían o principio, establecido no seu artigo 13.2, de garantir que "todos os alumnos teñen 
o dereito a recibi-lo seu primeiro ensino na súa lingua materna" (Xunta de Galicia, 14 de xullo do 1983: 1896). Ademais, no caso do Decreto 247/1995, o inmediatamente posterior ao $124 / 2007$, tamén se recollía que os profesores debían "ter en conta a lingua ambiental e coidar que [o alumnado] adquira de forma oral e escrita o cońecemento da outra lingua oficial de Galicia, dentro dos límites propios da correspondente etapa ou ciclo" (Consellería de Educación e Ordenación Universitaria, 15 de setembro do 1995: 2). Non obstante, para poder cumprir estes dous artigos da Lei de normalización e do Decreto 247, estaban presentes tres factores problemáticos sinalados por Martínez, Sobrińo e Varela (2002: 572): a) a ausencia dunha metodoloxía de rigor que permitise acudir a fontes científicas e especialistas para determinar a lingua predominante na contorna; b) a imposibilidade, debido ao contexto interactivo e dinámico das clases, de atender de maneira individualizada ao alumnado cunha lingua inicial diferente dun xeito eficaz; e c) o mantemento de actitudes indiferentes, se non directamente reprobatorias, cara á lingua galega.

Para intentar suplir estas carencias, no Decreto 124/2007 respectouse o devandito artigo 13.2 da lei, como dixemos, pero garantindo que tivese unha aplicación real tanto para o alumnado castelanfalante como galegofalante. Para iso, a lingua empregada en cada centro sería determinada mediante a consulta dos datos achegados polo Mapa Sociolingüistico de Galicia 2004, co obxectivo de cońecer a lingua predominante da contorna e combinando estes cońecementos coa información dos pais e dos datos estatísticos oficiais. Ademais, co obxectivo de garantir o desenvolvemento das competencias en galego por parte do alumnado castelanfalante, por unha banda, e de garantir que o galegofalante tivese acceso ao primeiro ensino na súa lingua propia (tal e como se recolle na Lei de normalización), por outra, no decreto tamén se introduce o uso do galego nun mínimo do $50 \%$ do horario total de cada ano (Consellería de Educación e Ordenación Universitaria, 29 de xuño do 2007: 11248).

Por outra banda, e considerando a preocupante situación da lingua galega neste chanzo educativo, o amparo xurídico do Decreto 124/2007 permitiu aos centros situados en contornas castelanfalantes que así o desexasen desenvolver programas en que o galego era a lingua predominante nas aulas, tal e como se recollera previamente no Plan xeral (Xunta de Galicia 2006: 102). Estes programas, cómpre engadir, eran de carácter totalmente voluntario, e desenvolvéronse co obxectivo de proporcionarlle ao alumnado castelanfalante o contacto suficiente co galego como para que puidesen acadar unha competencia axeitada neste idioma.

De entre todos os programas deste tipo que se desenvolveron durante os tres cursos en que estivo en vigor o Decreto 124/2007, nós destacamos aquí os resultados obtidos na Escola de Educación Infantil A Pastora, situada en Cambados. De acordo con Varela e Oubiña, dúas das docentes que participaron no programa, as razóns que as levaron a desenvolver esta iniciativa debíase a que as persoas responsables do centro observaban con preocupación o alarmante descenso de usos en galego por parte da minoría galegofalante, que a medida que avanzaba cada curso acababa empregando o 
castelán pola simple interacción co resto de compañeiros galegofalantes (2011:70-71). Despois de implantar un grupo escolarizado integramente en galego en cada curso, observouse que unha maioría de alumnado castelanfalante ía mudando os seus hábitos lingüísticos cara ao galego, acadando deste xeito unha competencia moi desenvolta nesta lingua, sen que por iso se vise prexudicada a súa competencia en castelán (Varela \& Oubiña 2011: 70-74). Estes resultados, que deixan constancia da efectividade de utilizar o galego como a lingua prioritaria nas aulas, deberán ser tidos en conta máis adiante para valorar os modelos de ensino bilingüe que se aplicaron con cada decreto.

\subsubsection{Primaria, ESO e Bacharelato: o galego como lingua vehicular e lingua de interacción nun mínimo do $50 \%$ das clases}

No Decreto 247/1995, o inmediatamente anterior ao $124 / 2007$, unicamente se recollía a recomendación de que o profesorado intentase que os discentes empregasen a lingua nas materias destinadas ao seu uso (Consellería de Educación e Ordenación Universitaria, 15 de setembro do 1995: 2), pero sen establecer directrices de ningún tipo para intentar seguir este principio. En consecuencia, aínda que a lingua fose utilizada nos exercicios e materiais escritos e polo profesor, o alumnado castelanfalante podía empregar este idioma nas materias reservadas ao uso do galego sen ningún tipo de sanción aplicada ao respecto. En definitiva, estes factores, unidos á escasa porcentaxe de materias impartidas en galego, provocaban que os discentes non puidesen adquirir unha competencia en galego equiparable ao castelán (Iglesias 2002: 151).

Como xa sinalamos máis arriba, coa aplicación do Decreto 124/2007, o galego foi por vez primeira a lingua prioritaria no ensino non universitario, pois debía empregarse nun mínimo do $50 \%$ das horas totais de cada curso, de acordo co previamente establecido no Plan xeral de normalización da lingua galega (Xunta de Galicia 2006: 103-104), sen chegar a especificarse unha porcentaxe máxima para a súa presenza (exceptuando as restantes materias de lingua, nas que debía utilizarse o idioma correspondente), e deixando aos centros o libre criterio de decidir se a partir da dita porcentaxe optaban por empregar a lingua en máis materias. En calquera caso, as materias que tińan que ser impartidas obrigatoriamente no idioma propio foron, de acordo co propio texto do decreto (Consellería de Educación e Ordenación Universitaria, 29 de xuño do 2007: 11247-11248), as seguintes: a) na Educación Primaria, as áreas de matemáticas, cońecemento do medio natural, social e cultural e educación para a cidadanía e dereitos humanos; b) na Educación Secundaria Obrigatoria, ciencias da natureza, ciencias sociais, xeografía e historia, matemáticas e educación para a cidadanía. No que ao Bacharelato respecta, se ben no texto non se chegan a establecer as materias específicas que estaban reservadas para o uso do galego, si que se establece o mínimo do $50 \%$ que tamén queda reservado para o resto de niveis educativos. 
Porén, o uso da lingua galega nun mínimo da metade das clases non foi a única medida favorable ao galego que se recollía no texto, pois tamén se establecía a obriga de que "nas áreas, materias ou módulos impartidos en lingua galega" o alumnado empregase "con carácter xeral o galego nas manifestacións oral e escrita" (Consellería de Educación e Ordenación Universitaria, 29 de xuño do 2007: 11249). Noutras palabras, o galego convertiríase non só na lingua vehicular das clases (isto é, a propia dos materiais didácticos, as actividades e a empregada polo docente), senón tamén na lingua de interacción (a utilizada polos alumnos nas aulas, nas súas intervencións orais cotiás).

Atopámonos, en definitiva, ante unha disciminación positiva da lingua galega na que, mediante a obriga de empregala en todos os contextos das materias destinadas ao seu uso, pretendíase contrarrestar ou compensar a hexemonía do castelán do resto da sociedade, garantir os dereitos lingüísticos dos estudantes galegofalantes (evitando que a escola funcione como un axente castelanizador) e posibilitar que o castelanfalante entrase en contacto co galego para posuír unha competencia bilingüe, tal e como se recolle no artigo 14.3 da Lei de normalización lingüística, sobre o que xa nos detivemos na epígrafe 3.2 .

\subsubsection{Un modelo de inmersión parcial para castelanfalantes e un modelo de mantemento para galegofalantes ${ }^{7}$}

Tal e como acabamos de ver, debido á escasa efectividade da lexislación lingüística precedente ao Decreto 124/2007, na maioría dos casos o alumnado castelanfalante de Galicia non posuía unha competencia en galego axeitada, nin tampouco tińa un contacto suficiente co idioma para que aumentasen os usos; ademais, no caso do alumnado galegofalante, o ensino chegaba a funcionar como un axente castelanizador, especialmente nos centros de Educación Infantil das contornas urbanas, debido ao escaso contacto que os discentes tiñan, e aínda teñen, coa lingua propia fóra do ámbito familiar. Tendo en conta as súas características xerais, e tomando como base as achegas de Iglesias (2017: 53-56) e Fernández, Lorenzo e Ramallo (2008: 63-65) na epígrafe 3.4, agora cómpre establecer os tipos de ensino bilingüe que se aplicaron co devandito decreto.

Deste xeito, e recordando os trazos básicos deste: a) uso do galego en Educación Infantil nun mínimo do 50\% do horario total dos centros de Educación Infantil que están situados en contornas castelanfalantes; b) uso desta mesma lingua nun mínimo do 50\% das horas totais en Educación Primaria e Educación Secundaria Obrigatoria; e c) nestes dous últimos niveis educativos, a obriga de que o galego fose tanto a lingua

7. Coincidimos con Iglesias (2017: 54-55) ao establecer cales son os modelos de ensino bilingüe que desenvolve cada decreto. 
vehicular (utilizada polo docente e a propia dos materiais curriculares) como a lingua de interacción (a empregada polo alumnado en tódalas intervencións orais e escritas) das materias destinadas ao seu uso, obtemos que o modelo de educación bilingüe para castelanfalantes consiste nun modelo de inmersión parcial.

Con todo, cómpre lembrar que no decreto non se establecía un número de horas máximo para empregar o galego en Educación Primaria e Educación Secundaria Obrigatoria, coa excepción das materias restantes de lingua, polo que os centros que así o desexasen podían empregalo en máis do mínimo do $50 \%$ estipulado. Ademais, varios centros de Educación Infantil tamén desenvolveron programas experimentais onde se utilizaba exclusivamente o galego, polo que tamén posibilitaba o desenvolvemento de modelos de inmersión total para castelanfalantes.

No caso do alumnado galegofalante, o decreto intentaba contrarrestar a presión social derivada do predominio do castelán en contextos alleos á casa e á familia, onde aprenderon o galego. Mediante a proxección dunha imaxe positiva do galego e a súa presenza prioritaria no ensino, aplícabase un modelo de mantemento para evitar que se realizase un cambio de idioma, modificando o efecto castelanizador do ensino que caracterizara á lexislación anterior.

\subsection{Decreto 79/2010: unha diferenciación entre o igualitario e o equitativo}

Nas eleccións autonómicas do 2009, a coalición de goberno entre socialistas e nacionalistas finalizou coa vitoria do PPdG, desta vez baixo a presidencia de Alberto Núnez Feijóo. Deste xeito, despois de tres escasos cursos académicos de aplicación, o Decreto 124/2007 foi derrogado e substituíuse polo Decreto 79/2010, do 20 de maio, para o plurilingüismo no ensino non universitario de Galicia (Consellería de Educación e Ordenación Universitaria, 25 de maio do 2010: 9242-9247), actualmente en vigor. Con este texto eliminouse calquera tipo de uso prioritario do galego nas aulas, facendo un tratamento igualitario, dende unha perspectiva estritamente numérica, das dúas linguas oficiais, que describiremos ao longo desta epígrafe.

A grandes trazos, xa no preámbulo do texto pódese inferir a oposición dos PPdG a calquera tipo de discriminación positiva da lingua galega, aducindo que resulta fundamental continuar co modelo de "conxunción lingüística" que se desenvolvera cos decretos anteriores ao 124, e xustificando esta decisión pola necesidade de acadar

8. A este respecto, o uso da expresión de "conxunción lingüística" pode ser interpretada, ao noso xuízo de dúas maneiras: a) como unha defensa, por parte do PPdG, dun tratamento de linguas que posibilita unha suposta situación de convivencia pacífica entre as dúas linguas, concepción que durante os anos noventa foi acuñada co termo de "bilinguismo harmónico" (Regueiro 1996: 1140-1142); e b) a defensa do principio de non separación lingüística do alumnado por razón de lingua, principio previamente recollido no artigo 13.3 da Lei de normalización (Xunta de Galicia, 14 de xullo do 1983: 3). 
un dominio pleno dos dous idiomas oficiais e, a maiores, de polo menos unha lingua estranxeira (a cursiva é nosa):

O Decreto 124/2007, do 28 de xuño, orientouse nomeadamente cara á obtención dunha competencia axeitada en lingua galega no ensino obrigatorio, sen o establecemento dun número ou porcentaxe mínima de materias impartidas en lingua castelá, o cal podería chegar a cambiar o modelo de conxunción de linguas desenvolvido en Galicia desde o inicio da autonomía e aceptado por todos os galegos e galegas

[...]

Esta nova realidade exixe un marco educativo que atenda esta necesidade social, posibilitando a capacidade efectiva do alumnado nas dúas linguas oficiais e nunha ou varias linguas estranxeiras (Consellería de Educación e Ordenación Universitaria, 25 de maio do 2010: 9242).

Tendo en conta o anterior, é este o momento en que cómpre formular un novo marco normativo para o ensino non universitario que regule a distribución das linguas vehiculares das distintas materias de estudo e que teña como obxectivos o de garantir a competencia plena e en igualdade nas dúas linguas oficiais (Consellería de Educación e Ordenación Universitaria, 25 de maio do 2010: 9242).

O motivo polo que destacamos algúns fragmentos do texto anterior débese a que estes conteñen, precisamente, o argumentario que empregou o PPdG para defender a distribución de linguas a partes iguais que impera no Decreto 79/2010: para os conservadores, o modelo de "conxunción lingüística" permitía que o alumnado acadase unha competencia plena en galego e castelán, rexeitando para iso calquera tipo de discriminación positiva cara ao galego que predominaba no Decreto 124/2007. Ignoraron, pois, varios aspectos clave aos que xa nos vińemos referindo anteriormente: a) os resultados positivos doutros territorios en que se desenvolveron programas de inmersión, tales como a provincia canadiense de Quebec ou Cataluña, tal e como expuxemos nas epígrafes 3.4. e 3.5.; b) dentro da propia Galicia, traballos de avaliación de competencias como o do Instituto de Ciencias da Educación (ICE de agora en adiante) (Silva 2010), xa desenvolto na sección 3.2., que amosaban que o modelo de linguas desenvolto ata o momento no ensino non garantía a adquisición de competencias bilingües ${ }^{9}$; ) o predominio do castelán no resto de ámbitos da sociedade, o que permitía que o cońecemento do castelán estivese máis que garantido.

Tamén merece especial mención que, no que respecta á distribución de linguas por materias, con este novo decreto permítese que os centros que dispoñen de proxectos plurilingües incorporen unha lingua estranxeira como o terceiro idioma vehicular do currículo, de maneira que nestes casos a porcentaxe de uso do galego queda

9. Aínda que no momento da realización do estudo do IGE xa se aplicara o Decreto 124/2007, os poucos anos en que permaneceu vixente non permitiron obter resultados concretos na competencia lingüística do alumnado. 
reducida a un terzo do horario total. Esta decisión xustífícase no texto polos efectos da globalización, pero parece responder máis a unha mercantilización das linguas que a un verdadeiro compromiso por acadar unha competencia semellante en varios idiomas:

A realidade social europea en que vivimos, nun contexto de globalización e de mobilidade laboral, sitúanos nun espazo internacional de plurilingüismo. Esta nova realidade exixe un marco educativo que atenda esta necesidade social, posibilitando a capacitación efectiva do alumnado nas dúas linguas oficiais e nunha ou varias linguas estranxeiras (Consellería de Educación e Ordenación Universitaria, 25 de maio do 2010: 9242).

Os resultados puxeron de manifesto a necesidade de revisar o marco legal que regula as linguas como elementos vehiculares do ensino, advertiron da relevancia outorgada á aprendizaxe do inglés, ao lado das dúas linguas oficiais, e da aposta da sociedade galega por unha presenza equitativa das dúas linguas oficiais nun sistema educativo plurilingüe (Consellería de Educación e Ordenación Universitaria, 25 de maio do 2010: 9243).

Con este tipo de discurso, o PPdG pretendeu xustificar un modelo de ensino de linguas que lle concede ao castelán e ao inglés o mesmo grao de presenza co galego nas aulas, ignorando a desigualdade lingüística de base que impera non só en Galicia (entre o galego e o castelán), senón tamén no mundo moderno, debido ao valor que se lle concede ás frecuentemente chamadas "linguas globais", consideradas unicamente polo seu potencial sociopolítico e económico. Noutras palabras, dende esta perspectiva os idiomas son concibidos como simples ferramentas que permiten a inclusión nun mercado laboral cada vez máis competitivo, pero sen ter en conta o respecto pola diversidade lingüística e polas linguas autóctonas e propias dun determinado territorio. Tal e como expón Ramallo (2017: 60), falamos dunha "mercantilización da lingua, sen outra finalidade que obedecer as 'ordes' dunha razón neoliberal deseńada para promover o fortalecemento do capital humano como única saída ao suxeito emprendedor".

Partindo deste argumentario, as características fundamentais do decreto correspóndense, precisamente, con todo o que se anulou do texto do bipartito. Tal e como fixemos na sección de análise do Decreto 124/2007, nesta nova epígrafe analizaremos máis en detalle cada un destes trazos que definen o Decreto 79/2010 e as súas diferenzas co texto anterior, clasificando os contidos en función do nivel educativo no que se aplican.

\subsubsection{Educación Infantil: consulta aos pais e lingua predominante na contorna}

No tocante ao primeiro nivel de ensino, en todos os decretos de distribución de linguas que se foron sucedendo dende os anos oitenta ata a actualidade respectouse o 
principio, recollido na Lei de normalización, de que "todos os alumnos teñen o dereito a recibi-lo seu primeiro ensino na súa lingua lingua materna" (Xunta de Galicia, 14 de xullo do 1983: 1896). En todo caso, se ben no Decreto 124/2007 tamén se respectaba este criterio, tal e como vimos na sección 4.1., tamén se tiñan en conta os datos obtidos a través de fontes de consulta como o Mapa Sociolingüistico de Galicia, para así saber cal era a lingua predominante no alumnado.

Porén, mentres que no texto do bipartito se consideraban o criterio das familias, os datos estatísticos e as fontes especializadas por igual, nun inicio no Decreto 79/2010 o PPdG unicamente tińa en conta "unha pregunta que se efectuará aos pais, nais, titores/as ou representantes legais" (Consellería de Educación e Ordenación Universitaria, 25 de maio do 2010: 9244) para decidir con obxectividade cal era a lingua máis empregada na contorna. Neste sentido, deixar a responsabilidade total desta decisión no criterio dos pais suporía un factor de risco que podería derivar nun predominio absoluto do castelán en Educación Infantil, tendo en conta que moitas xeracións de falantes aínda manifestan unhas actitudes que, se ben non son directamente negativas cara ao galego, tenden a amosar unha preferencia social polo castelán. Como afirman Janeiro e Álvarez (2013a: 19), "é ben cońecida a histórica negación da identidade galegofalante nunha ampla masa social onde aínda aniña unha diglosia inculcada a ferro. Polo tanto, un risco engadido é que a información familiar responda máis ao desexo ca á realidade".

Debido a esta perigosidade de delegar a decisión exclusivamente nos pais e nais, e considerando o mantemento de actitudes que privilexian ao castelán como unha lingua de maior prestixio, a Mesa pola normalización lingüística interpuxo un recurso ante o Tribunal Superior de Xustiza de Galicia, que acabou derrogando este punto do decreto na sentenza 1286/2012 (Janeiro \& Álvarez 2013b: 13-14), na que tamén se anulou a libre elección da lingua empregada polo alumnado, tal e como describiremos na seguinte epígrafe.

Por outra banda, a eliminación, nas contornas urbanas, da introdución compensatoria do galego trouxo consigo dúas consecuencias principais: a) a eliminación dun dos escasos contextos de contacto, se non o único, coa lingua por parte das novas xeracións de castelanfalantes das grandes cidades galegas; e b) o incumprimento, por parte do PPdG, dun Plan xeral de normalización no que se recollía a necesidade de "fixar, como mínimo, un terzo do horario semanal en galego nestas etapas educativas para os contextos e contornos nos que a lingua predominante sexa o castelán" (Xunta de Galicia 2006: 102), e que no Decreto 124/2007 se aumentara ata un mínimo do $50 \%$.

Non obstante, e a pesar de que o Decreto 79/2010 xa non permite un uso do mínimo do $50 \%$ nas contornas castelanfalantes, séguese recollendo a obriga do profesorado de procurar "que o alumnado adquira, de forma oral e escrita, o cońecemento da outra lingua oficial de Galicia dentro dos límites da etapa ou ciclo" (Consellería de Educación e Ordenación Universitaria, 25 de maio do 2010: 9244). O problema 
que xorde aquí é que en ningún momento se especifica que grao de presenza debe ter o galego nestes contornos, o que provoca, segundo Iglesias (2018:151) que "estes apartados da lexislación apenas se aplican na práctica, pois na maior parte dos casos os centros decántanse pola lingua predominante entre o alumnado, introducindo a outra de forma anecdótica ou incluso obviándoa totalmente".

De feito, neste mesmo traballo a autora comproba que tipo de competencias lingüísticas se obteñen, coa aplicación do decreto, en alumnado de diferentes perfís sociolingüísticos; para iso, aplicouse unha entrevista ao alumnado de Educación Infantil cunha parte de conversa espontánea, e con outra parte baseada nun exercicio de identificación de imaxes. Ante a ausencia do suficiente input en galego da escola, considerada como o principal axente que podería reverter a falta de contacto con esta lingua nas contornas castelanfalantes, o estudo extrae dúas conclusións básicas sobre as competencias do alumnado situado nestes contextos: a) a maioría do alumnado, castelanfalante, non parece posuír un dominio equilibrado das dúas linguas, pois na parte de identificación de imaxes nomeaban case todas en castelán, sen ser quen de dicilo en galego; b) dos seis nenos galegofalantes de contornas castelanfalantes que participaron neste mesmo exercicio, cinco nomearon as imaxes maioritariamente en castelán, o que tamén parece deberse a un descenso nos usos do galego destes mesmos falantes, debido (entre outros factores) ao efecto castelanizador da escola (Iglesias 2018: 152-157).

\subsubsection{Primaria, ESO e Bacharelato: reparto igualitario de linguas por materias e liberdade idiomática do alumnado}

O decreto do plurilingüismo baséase nun reparto equitativo de linguas, de maneira que un $50 \%$ das materias pasan a ser impartidas en galego e outro $50 \%$ en castelán. Esta porcentaxe, cómpre engadir, queda reducida a un $33 \%$ para cada lingua nos centros que incorporan unha lingua estranxeira como a vehicular dunha parte do currículo (Consellería de Educación e Ordenación Universitaria, 25 de maio do 2010: 9244).

No que respecta á lingua de interacción das aulas, isto é, aquela que debe utilizar o alumnado en todas as súas intervencións, no decreto recollíase, no seu artigo 12.3, o dereito dos discentes de empregar "a lingua oficial da súa preferencia", pero coa imprecisa recomendación de "procurar que os e as estudantes utilicen a lingua en que se imparte a área, materia ou módulo" (Consellería de Educación e Ordenación Universitaria, 25 de maio do 2010: 9245), tal e como se recollía no Decreto 247/1995. Porén, este punto deste artigo foi suprimido polo Tribunal Superior de Xustiza de Galicia na xa mencionada sentenza 1286/2012 (Janeiro \& Álvarez 2013b: 13-14), ao considerar que a libre elección do alumnado non actuaba en consecuencia co artigo 14.3 da Lei de normalización lingüística, antes descrito, segundo o cal os alumnos 
debían posuír un cońecemento similar dos dous idiomas ao remataren cada ciclo educativo (Lei 3/1983: 1896). Polo tanto, debido a esta decisión do tribunal, o factor da obriga explícita de empregar o galego que predominaba no decreto do bipartito segue a estar presente no novo texto.

En esencia, coa aplicación do Decreto 79/2010 os populares anularon todos os usos prioritarios do galego que se fixeran co decreto anterior, rexeitando calquera medida compensatoria do idioma e obviando a situación de desigualdade entre os dous idiomas en calquera ámbito das esferas pública e privada de Galicia. Neste senso, non só se incumpría o establecido no Plan xeral de normalización no 2004, senón que tamén se ignoraban algúns dos puntos básicos da Lei de normalización, tales como priorizar o uso da lingua no ensino ou garantir unha competencia equiparable nos dous idiomas. De feito, traballos como os de Silva (2010: 62; 82) e Iglesias (2018: 152-157), xa mencionados anteriormente, parecen indicar que este domino equiparable non chega a producirse, e o alumnado remata o ensino básico cunha competencia inferior en galego ca en castelán.

Dito doutro xeito, fíxose un tratamento supostamente igualitario entre o galego e o castelán nas aulas, pero sen ter en conta que, de acordo co marco legal vixente, estas deberían funcionar como un axente compensatorio da devandita desigualdade. Desta maneira, e coincidindo con Villares (2010: 46), o tratamento igualitario (división a partes iguais do grao de presenza de cada lingua) debería ser considerado non como un medio, senón como un fin que se debe acadar unha vez se acade a normalización ou igualdade plena entre o galego e o castelán; mentres tanto, o medio para obter ese obxectivo sería un predominio do uso do galego neste ámbito (o realmente equitativo).

\subsubsection{Un modelo de submersión para galegofalantes}

Como puidemos ver na análise deste decreto, unha distribución de linguas por materias do $50 \%$ para cada lingua, que queda reducida a un terzo para os centros que incorporan un idioma estranxeiro como vehicular, non permite que o alumnado galegofalante situado en contornas urbanas poida empregar a súa lingua propia sexa con normalidade. Por este motivo, o Decreto 79/2010 desenvolveu, acudindo de novo aos traballos de Iglesias (2017: 54-55) e Fernández, Lorenzo e Ramallo (2008: 66), un modelo de submersión para os estudantes galegofalantes destes contextos, recuperando a escola a función castelanizadora que viñera desempeñando en tódolos decretos de distribución de linguas anteriores ao 124/2007. 


\section{Conclusións e reflexión final}

Coa aprobación unánime do Plan xeral de normalización da lingua galega no 2003, sentáronse as bases para que a coalición de goberno entre o PSdG e o BNG elaborase un decreto co que, por primeira vez na historia, se priorizaría o uso do galego nas aulas. Tal e como puidemos ver nas páxinas anteriores, coas medidas do Decreto 124/2007 desenvolvéronse dous modelos de ensino bilingüe: un de mantemento da lingua propia para o alumnado galegofalante e outro de inmersión parcial para o castelanfalante, deixando á elección dos centros que o grao de uso da lingua galega se aumentase para obter un programa de inmersión total. Un exemplo disto constitúeno os programas experimentais que desenvolveron numerosos centros de Educación Infantil situados en contornas castelanfalantes.

Non obstante, non se puido realizar unha comprobación dos efectos da aplicación do Decreto 124/2007 sobre as competencias lingüísticas do alumnado galego: despois de estar só tres cursos académicos en vigor, o retorno do PPdG ao goberno da Xunta derrogou o texto e substituíuno polo Decreto 79/2010, actualmente en vigor. Como xa puidemos comprobar, eliminouse calquera tipo de priorización da lingua galega nas aulas, facéndose un reparto lingüístico distribuído a partes iguais entre o castelán e o galego, que podía quedar reducido a un terzo no caso dos centros que incorporaban o inglés como o terceiro idioma do currículo. Ante a negación dun contacto suficiente coa súa lingua propia no ámbito educativo, este decreto funciona como un modelo de submersión para o estudantado galegofalante de contornas castelanófonas, converténdose a escola nun axente castelanizador, tal e como ocorría antes de que se aplicase o texto do bipartito. Atopámonos, pois, ante o primeiro decreto de distribución de linguas que retrocede no proceso de inclusión do galego no ensino dende que se aprobou a Lei de normalización lingüística.

Despois da análise dos dous decretos, podemos inferir que, ademais dos modelos de ensino bilingüe que aplicou cada goberno, as ideoloxías lingüísticas que o separan son moi diferentes. No caso da coalición entre socialistas e nacionalistas, estes parecían ser plenamente conscientes da desigualdade social entre o galego e o castelán. A súa proposta, en definitiva, foi a de facer un uso compensatorio do galego para que todo o alumnado, independentemente de cal fose a súa lingua, acadase unhas competencias bilingües axeitadas. No que respecta á metodoloxía máis axeitada para conseguilas, os estudos sobre o ensino bilingüe extraen que o camiño máis axeitado para conseguilo é mediante a inmersión na lingua máis débil. Tal e como afirma Iglesias (2018: 157), “o máis recomendable é o ensino na lingua menos prestixiada socialmente, é dicir, un programa de inmersión (total ou parcial), xa que a lingua dominante xa conta con suficientes vías de entrada fóra da escola e, polo tanto, a súa competencia está garantida”. Noutras palabras, co Decreto 124/2007 realizouse, como xa mencionamos en varias ocasións ao longo deste traballo, unha priorización do galego nas aulas para 
intentar contrarrestar a desigualdade que impera no resto na sociedade. Neste senso, esta devandita priorización da lingua nas aulas constitúese como un medio para acadar a igualdade plena entre ambos os dous idiomas no conxunto da sociedade.

Aínda que é frecuente atopármonos con opinións que cuestionan a efectividade dos programas de inmersión e mantemento na competencia dos falantes das linguas implicadas, as investigacións realizadas ao respecto parecen indicar que, con estes modelos, as competencias en ambas as dúas linguas están máis que garantidas, independentemente de que a lingua do estudante sexa unha ou outra. De feito, o predominio do idioma privilexiado (neste caso o castelán) nos contextos alleos á escola garante que ningún galego posúa competencias deficitarias nesta lingua, tal e como sinalan grupos de investigación como o Seminario de Sociolingüística (2016: 38) ou institucións como o ICE, nun estudo xa tratado na epígrafe 3.2. (Silva 2010). Por outra banda, os resultados positivos dos programas experimentais de inmersión total en Educación Infantil, aos que xa nos refirimos na sección 4.1.1., amosan que unha exposición xa non só parcial, senón total en galego, permitiu que o alumnado castelanfalante que participou nestes proxectos acadase unha competencia lingüística inicial moi semellante en ambos os dous idiomas. Ademais, fóra do ámbito galego, tamén destacan os datos achegados por estudos como os realizados en Cataluña ou en Quebec, que reforzan aínda máis esta concepción positiva dos programas de inmersión e mantemento das linguas menos privilexiadas.

Polos motivos que acabamos de expoñer, resulta evidente que o modelo de linguas aplicado no Decreto 79/2010 obvia a desigualdade lingüística de base que impera en Galicia. Aínda que resultan necesarios máis traballos que examinen o impacto da aplicación deste decreto sobre as competencias lingüísticas en galego dos alumnos, os escasos estudos realizados ao respecto (Iglesias 2018; Silva 2010), indican a menor competencia en galego do alumnado e a castelanización á que se ven sometidos o estudantes galegofalantes das contornas urbanas e semiurbanas, especialmente na Educación Infantil.

Con todo, cómpre mencionar que, aínda que neste artigo fixemos unha análise dos decretos baseándonos na adquisición de competencias, a súa aplicación tamén terá un influxo sobre as actitudes e, especialmente, sobre os usos lingüísticos dunha lingua ou doutra. Como exemplo, basta con considerar que, nos programas de inmersión, a adquisición de competencias bilingües facilitará a liberdade de escolla entre un idioma ou outro, de xeito que a mocidade castelanfalante podería ter unha maior predisposición a usar esta lingua, mentres que a galegofalante disporía dun aliciente para conservar o seu idioma propio.

En síntese, a análise que realizamos ao longo das páxinas anteriores evidencia que, mentres que o goberno bipartito asumiu un compromiso pola normalización do galego e a adquisición dunha competencia plena por parte de toda a mocidade, o PPdG aplicou un decreto que rexeita o camiño que parece máis propicio para acadar a igualdade plena entre as linguas galega e castelá. Neste senso, cómpre desenvolver unha actividade investigadora que permita comprender cal foi o contexto discursivo 
que rodeou a estes dous decretos, cunha dobre finalidade: a) coñecer cales foron os erros cometidos polo bipartito, máis alá da simple derrota electoral, ao non ser quen de facer chegar á sociedade os obxectivos que se perseguían co Decreto 124/2007; b) inferir que tipo de estratexias empregou o PPdG para ocultar a súa verdadeira ideoloxía lingüística, traducida nun texto que parece prexudicar enormemente á lingua galega no ensino como o Decreto 79/2010. 


\section{Referencias bibliográficas}

Baker, Colin. 1997. Fundamentos de educación bilingüe y bilingüismo. Madrid: Cátedra. (Tradución de Ángel Alonso; primeira edición en inglés 1993).

Consellería de Educación e Ordenación Universitaria. Decreto 247/1995, do 14 de setembro, polo que se desenvolve a Lei 3/1983, do 15 de xuño, de normalización lingüística, para a súa aplicación ó ensino en lingua galega nas ensinanzas de réxime xeral impartidos nos diferentes niveis non universitarios. Diario Oficial de Galicia, 15 de setembro de 1995, 178, 6991. https://www. xunta.gal/dog/Publicados/1995/19950915/Anuncio4366_gl.html

Consellería de Educación e Ordenación Universitaria. Decreto 124/2007, do 28 de xuño, polo que se regula o uso e a promoción do galego no sistema educativo. Diario Oficial de Galicia, 29 de xuńo do 2007, 125, 11247-11251. https:/www.xunta.gal/dog/Publicados/2007/20070629/Anuncio22B3A_gl.html

Consellería de Educación e Ordenación Universitaria. Decreto 79/2010, do 20 de maio, para o plurilingüismo non universitario de Galicia. Diario Oficial de Galicia, 25 de maio do 2010, 97, 92429247. https://www.xunta.gal/dog/Publicados/2010/20100525/Anuncio196D2_gl.html

Constitución Española. Boletín Oficial del Estado, 29 de decembro do 1978, 29313-29424. https:// www.boe.es/eli/es/c/1978/12/27/(1)

Cortès-Colomé, Montserrat. 2011. Els alumnes acaben l'escolarització obligatòria amb dèficits en els coneixements de castellà pel fet d'estudiar (principalment) en llengua catalana? En Miquel Strubell i Trueta, Llorenç Andreu Barrachina, Elena Sintes Pascual \& Melina Aparici Aznar (coords.), Resultats del model lingüistic escolar de Catalunya: l'evidència empirica. 23-28. Barcelona: Universitat Oberta de Catalunya.

Costas, Xosé-Henrique (coord.). 2009. 55 mentiras sobre a lingua galega. Santiago de Compostela: Laiovento.

Cummins, Jim. 1983. Interdependencia lingǘstica y desarrollo educativo de los nińos bilingües. Infancia y Aprendizaje 21, 37-61. https://doi.org/10.1080/02103702.1983.10821962

Fernández, Agustín / Anxo Lorenzo \& Fernando Ramallo. 2008. A planificación lingüística nos centros educativos. Santiago de Compostela: Xunta de Galicia.

Iglesias, Ana. 2002. Falar galego: "no veo por qué". Aproximación cualitativa á situación sociolingüística de Galicia. Vigo: Xerais.

Iglesias, Ana. 2017. Programas de inmersión, mantemento e submersión das linguas de Galicia. Revista Galega de Educación 69, 50-57.

Iglesias, Ana. 2018. Consecuencias do Decreto do plurilingüismo (79/2010) no proceso de adquisición lingüística. En Ana Acuña, Xosé-Henrique Costas \& Ana Iglesias (eds.), Homenaxe a Ramón Gutiérrez. 143-161. Vigo: Servizo de Publicacións da Universidade de Vigo.

Janeiro, Xosé Luis \& Andrés Alonso. 2013a. A lingua galega no ensino: reflexións sobre o decreto 124/2007. A letra miúda. Revista de sociolingüistica para o ensino 3. http://coordinadoraendl.org/ aletramiuda/index.php?art=art5_n3.html (12/11/2018).

Janeiro, Xosé Luis \& Andrés Alonso. 2013b. O decreto 79/2010: Penélope e a lexislación lingüística. $A$ letra miúda. Revista de sociolingüistica para o ensino 4. http://coordinadoraendl.org/aletramiuda/ index.php?art=art4_n4.html (12/11/2018). 
Lambert, Wallace. 1981. Un experimento canadiense sobre desarrollo de competencia bilingüe: programa de cambio de lengua hogar - escuela. Revista de Educación 268, 167-177.

Lei 3/1983, de 15 de xuño, de normalización lingüística. Diario Oficial de Galicia, 14 de xullo do 1983, 84, 1893-1899.

Ley Orgánica 1/1981, del 6 de abril, del Estatuto de Autonomía para Galicia. Boletín Oficial del Estado, 28 de abril do 1981, 8997-9003.

Loredo, Xaquín \& Bieito Silva. 2014. Variables asociadas á competencia gramatical e léxica en galego e castelán do alumnado de Galicia ao final do ensino obrigatorio. Revista de Investigación en Educación 12, 191-208. http://reined.webs.uvigo.es/index.php/reined/article/view/257

Lorenzo, Anxo. 2005. Planificación lingüística de baixa intensidade: o caso galego. Cadernos de lingua $27,37-59$.

Martínez, Mónica, M.a Anxos Sobrińo \& Begońa Varela. 2002. Política lingüística e educativa en Galicia: primeiros niveis de ensino. En María Xesús Bugarín (ed.), Actas da VII Conferencia Internacional de Linguas Minoritarias. 571-579. Santiago de Compostela: Xunta de Galicia.

Ministerio de Educación. Real Decreto 1981/1979, del 20 de julio, por el que se regula la incorporación de la Lengua Gallega al sistema educativo en Galicia. Boletín Oficial del Estado, 200, 21 de agosto do 1979, 19550. https://www.boe.es/eli/es/rd/1979/07/20/1981

Monteagudo, Henrique \& Xan Bouzada. 2002. O proceso de normalización do idioma galego. 19802000. Volume II. Educación. Santiago de Compostela: Consello da Cultura Galega. http://consellodacultura.gal/publicacion.php?id=315

Pérez, Rosario. 2011. Recensión de Avaliación da competencia do alumnado de 4. ${ }^{\circ}$ da ESO nos idiomas galego e castelán, de Bieito Valdivia (ed.). Estudos de Lingüistica Galega 3, 291-295.

Plataforma per la Llengua. 2018. La inmersión lingüistica en Cataluña: un modelo eficaz y de éxito. https:// www.plataforma-llengua.cat/media/upload/pdf/immersio-cast_1537173291.pdf. (29/12/2018)

Ramallo, Fernando. 2017. "Vigo en inglés", unha política lingüística urbana neoliberal. A Trabe de Ouro 106, 57-66.

Regueiro, Manuel. 1996. Bilingüismo harmónico: modelo social posible. En María del Carmen Cabeza / Anxo Lorenzo \& Xoán Paulo Rodríguez (eds.): Comunidades e individuos bilingües. Actas do I Simposio Internacional sobre o Bilingüismo. Vigo: Servizo de Publicacións da Universidade de Vigo.

Sánchez, Pablo. 2018. Os idiomas do estado español: un enfoque sociolingüístico. Santiago de Compostela: Servizo de Publicacións da Universidade de Santiago de Compostela. http://dx.doi. org/10.15304/9788416954834. https://www.boe.es/eli/es/rd/1979/07/20/1981

Seminario de Sociolingüística. 1994. Lingua inicial e competencia lingüistica en Galicia. Santiago de Compostela: Real Academia Galega.

Seminario de Sociolingüística. 1995. Usos lingüisticos en Galicia: Compendio do II Volume do Mapa Sociolingüistico de Galicia. Santiago de Compostela: Real Academia Galega. http://publicacions. academia.gal/index.php/rag/catalog/book/128

Seminario de Sociolingüística. 2016. Lingua e sociedade en Galicia. A evolución sociolingüistica 19922013. Santiago de Compostela: Real Academia Galega. http://publicacions.academia.gal/index. $\mathrm{php} / \mathrm{rag} / \mathrm{catalog} / \mathrm{book} / 305$

Serra, Josep. 2006. El plan de lengua y cohesión social en Cataluńa: primeros datos de una investigación. Cultura y Educación 18 (2), 159-172. https://doi.org/10.1174/113564006777973897 
Siguán, Miguel \& William Mackey. 1986. Educación y bilingüismo. Madrid: Santillana.

Silva, Bieito (ed.). 2010. Avaliación da competencia do alumnado de $4 .^{\circ}$ da ESO nos idiomas galego e castelán. Santiago de Compostela: Servizo de Publicacións da Universidade de Santiago de Compostela.

Subiela, Xaime. 2002. Política lingüística a debate. En Henrique Monteagudo, Socorro García Conde, Héctor López Ruíz de Castro \& Xaime Subiela, A normalización lingüistica a debate. 131-171. Vigo: Xerais.

Strubell i Trueta, Miguel, Andreu Barrachina Llorenç, Elena Sintes Pascual \& Melina Aparici Aznar (coords.). 2011. Resultats del model lingüistic escolar de Catalunya: l'evidència empírica. Barcelona: Universitat Oberta de Catalunya.

Varela, Amelia \& Dolores Oubiña. 2011. A experiencia das liñas de galego no EEI da Pastora, Cambados. En Bieito Silva, Xesús Rodríguez \& Isabel Vaquero (coords.), A planificación para a normalización lingüistica nos centros de ensino non universitarios. Actas das II Xornadas "Educación e linguas en Galicia". 65-74. Santiago de Compostela: Universidade de Santiago de Compostela.

Vila, Ignasi. 2011a. Els alumnes castellanoparlants acaben l'escolarització obligatòria amb dèficits en els coneixements escolars per culpa del fet d'estudiar en una llengua -la catalana- que no és la seva? En Miquel Strubell i Trueta, Llorenç Andreu Barrachina / Elena Sintes Pascual \& Melina Aparici Aznar (coords.), Resultats del model lingüistic escolar de Catalunya: l'evidència empírica. 11-14. Barcelona: Universitat Oberta de Catalunya.

Vila, Ignasi. 2011b. Els (o molts) alumnes castellanoparlants (i d'altres llengües) acaben l'escolarització obligatòria amb (importants) dèficits en els coneixements de català si no estudien (principalment) en llengua catalana? En Miquel Strubell i Trueta, Llorenç Andreu Barrachina, Elena Sintes Pascual \& Melina Aparici Aznar (coords.), Resultats del model lingüistic escolar de Catalunya: l'evidència empírica. 29-32. Barcelona: Universitat Oberta de Catalunya.

Vila, Ignasi. 2012. Algunhas reflexións sobre a educación bilingüe. A letra miúda. Revista de sociolingüistica para o ensino 1.

Villares, Luís. 2010. Estudo sobre a legalidade do "Decreto 79/2010 para o plurilingüismo non universitario de Galicia”. Unha perspectiva constitucional. En Luís Villares (coord.): Estudos xurídicos sobre o decreto para o plurilingüismo. Ames: Laiovento.

Xunta de Galicia. 2006. Plan Xeral de Normalización da Lingua Galega. Santiago de Compostela: Xunta de Galicia. 